\title{
Reducing Cooling and Heating Loads in Existing Residential Buildings in the Context of Building Envelope: Beykoz-Kanlıca
}

\author{
Bina Kabuğu Bağlamında Mevcut Konut Binalarında \\ Soğutma ve Isıtma Yüklerinin Azaltılması: Beykoz-Kanlıca \\ Funda ÖZTÜRK KERESTiCiOĞLU,' Derya Burcu TÜMER ÖZKAN, ${ }^{2}$ \\ Cenk HAMAMCIOĞLU, ${ }^{3}$ Bora YERLIYURT, ${ }^{3}$ Esra SAKINÇ, ${ }^{4}$ Tamer HAFIZOĞLU ${ }^{5}$
}

\section{ABSTRACT}

Turkey has undergone inadequate development during a process of rapid urbanization and growth since the 1950s, parallel to reduced construction costs for residential buildings. This has contributed to household energy consumption in Turkey growing to twice the global average, and twice the averages of European Union member states. In response, the Energy Efficiency Law and other energy performance regulations were enacted in 2007. As a part of "Assessing the Inventory for Renewable Energy Utilization in Existing Residential Buildings and Setting Up Local Design Parameters," supported by the Yıldız Technical University Scientific Research Projects Coordination Department, İstanbul's Beykoz District was chosen as the case area. Using solar energy for heating purposes is popular in Beykoz for a number of reasons, including the prevalence of mostly detached buildings and abundant green space, as well as less building density and fewer stories, compared to the city center. Four buildings were studied in order to identify improvements that would allow for a reduction in cooling and heating loads in existing residential buildings in the context of building envelopes. Research of the four existing residential buildings executes similar results. Results of the study of a multi-family residential building in the neighborhood of Kanlıca is presented. Determined by the calculation of cooling-heating loads and carbon emissions, improvements designed to efficiently utilize solar energy where the building envelope permits are identified. These improvements address window space, eaves, and characteristics, as well as exterior wall insulation thickness, draft prevention, shading, landscaping features, and control of solar energy. Average monthly and annual heating-cooling requirements were calculated using IESVE simulation software. The improvements yielded a $72 \%$ drop in annual heating energy consumption and a $24 \%$ drop in annual cooling energy consumption, resulting in an average drop of $62 \%$ in $\mathrm{CO}_{2}$ emissions.

Keywords: Beykoz; building envelope; energy performance; Kanlıca; residence; solar energy.

\section{ÖZ}

Türkiye'de kentleşme sürecinde plansız yapılaşma ve bina yapım maliyetlerinin düşük tutulması gibi unsurlar konut binalarında enerji tüketiminin Avrupa Birliği ülkeleri ortalamalarının iki kat gerçekleşmesine neden olmaktadır. Bu gidişat karşısında Türkiye'de 2007 yılından itibaren Enerji Verimliliği Kanunu ve Enerji Performans Yönetmeliği uygulamaya konularak, mevcut konut binalarının enerji tüketimi-kabuk ilişkisinde, yenilenebilir enerji kullanma performansının arttırılmasına yönelik iyileştirmelerin önemi vurgulanmıştır. YTÜ Bilimsel Araştırmalar Projeler Koordinatörlüğü tarafindan desteklenen "Mevcut Konut Stoğunda Yenilenebilir Enerji Kullanımına Yönelik Verilerin Değerlendirilmesi ve Tasarım Ölçütleri Iç̧in Yere Ait Bilgilerin Oluşturulması; Beykoz Örneği" isimli araştırma projesi kapsamında İstanbul'un Beykoz IIlçesi örneğinde yürütülen çalışmada çoğunluğu ayrık düzendeki yapılar, yeşil alanların çokluğu, yapı yoğunluğu ve kat adetlerinin kent merkezine göre daha az olması güneş enerjisini ön plana çıkarmıştır. Bu bağlamda Istanbul'un Beykoz Ilç̧esi'nde yürütülen çalışmalar dört farklı mevcut konut dokusunda belirlenen birer bina örnek seçilerek gerçekleştirilmiştir. Seçilen mevcut dört konut binasında gerçekleştirilen araştırma sonuçları benzer çıkmıştır. Dolayısıyla ilgili araştırma projesinin ürünü olan bu makalede Beykoz'daki Kanlıca yerleşmesinden seçilen çok ailelik konut binasının sonuçları paylaşılmaktadır. Seçilen binada ısıtma-soğutma yükleri ve $\mathrm{CO}_{2}$ salınımları hesaplanarak bina kabuğunda güneş enerjisinin de bina şartlarının elverdiği oranda sınırlı bir şekilde verimli kullanımını sağlayacak iyileştirmeler belirlenmiştir. Sözkonusu iyileştirmeler; pencere alanları, pencere saçakları, pencere özellikleri, dış duvar yalıtım kalınlığı, hava sızıntılarının engellenmesi, gölgeleme ve peyzaj elemanlarıyla güneş denetiminin sağlanması olarak belirlenmiştir. Makale belirlenen yöntemlerin uygulanması ve sonuçların gösterilmesini içermektedir. Iyileştirme parametreleri arasında bir ilişki kurulup herhangi bir çıkarım yapılmamıştır. Seçilen dört binadan biri olan ve bu makaleye konu olan Kanlıca'daki mevcut konut binasının aylık ve yıllık ortalama ısıtma-soğutma ihtiyaçları IESVE simülasyon programı kullanılarak hesaplanmıştrr. Iyileştirmeler sonunda binada yıllık ısıtma enerji tüketimi \%72 azalma sağlarken, yıllık soğutma enerji tüketimi \%24 düşmüş, buna bağlı binanın yaydığı $\mathrm{CO}_{2}$ miktarı \%62 azalmıştır.

Anahtar sözcükler: Beykoz; bina kabuğu; enerji performansı; Kanlıca; konut; güneş enerjisi.

'Department of Architecture, Yıldız Technical University, İstanbul, Turkey

${ }^{2}$ Department of Mechanical Engineering, Yıldız Technical University, İstanbul, Turkey

${ }^{3}$ Department of Urban and Regional Planning, Yıldız Technical University, İstanbul, Turkey

${ }^{4}$ Department of Interior Design, Maltepe University Faculty of Architecture, İstanbul, Turkey ${ }^{5}$ Venta Engineering, İstanbul, Turkey.

Article arrival date: January 19, 2015 - Accepted for publication: December 02, 2015

Correspondence: Cenk HAMAMCIOĞLU. e-mail: chamamcioglu@gmail.com

๑) 2015 Yıldız Teknik Üniversitesi Mimarlık Fakültesi - ๑ 2015 Yıldız Technical University, Faculty of Architecture 


\section{Introduction}

Consumption of non-renewable energy sources such as coal, natural gas and petroleum in human activities release harmful gases into the atmosphere. As a result, an increasing dependency on these resources to meet energy demand has turned out to be one of the biggest causes of pollution and climate change, which threaten the lives and future of all living organisms today. ${ }^{1,2}$ According to these alarming data released by the International Energy Agency (2013), $\mathrm{CO}_{2}$ emissions have increased more than two fold in the period between 1971 and 2011. On the other hand, $\mathrm{CO}_{2}$ emissions in Turkey during the same period have increased seven fold due to the factors such as industrialisation in nationwide, rapid urbanization, development of land, air transportation and increasing numbers in private vehicle ownership (Table 1).

Besides industrial buildings and transportation vehicles, one of the leading sources of harmful gases released into the atmosphere is residential buildings, which have long lifespans and use significant amounts of energy. As of 2011, residential buildings have become the third largest source of $\mathrm{CO}_{2}$ emissions (17\%) worldwide following industry and transport whereas in Turkey, residential buildings are the second largest source of $\mathrm{CO}_{2}$ emissions (24\%) following the industrial buildings (Table 2). The main sources of greater
$\mathrm{CO}_{2}$ emissions consumed by the residential buildings in Turkey are rapid population growth $(20,947,155$ in $1950-76,481,847$ in 2013) and urbanisation (18.5\% in 1950 to $75 \%$ in 2013) witnessed after the 1950 's. ${ }^{3}$ Unfavourable and illegally constructed buildings met a significant part of the demand for residences during this period. Architecture and engineering production costs in these buildings were minimised with almost no consideration to efficient energy use and maintenance costs that would be incurred throughout their lifespan. What is more, the architectural designs of buildings directly affect residents' energy consumption and costs. ${ }^{4}$ For countries like Turkey, which imports $73 \%$ of its energy demand ${ }^{5}$ brings added burden to the economy on a macro scale, while increasing energy cost per household. Besides poor awareness on energy saving, the main issues related to high household energy costs in Turkey include the failure to develop planning and architectural designs that consider geographical and climatic conditions of the building location, provide adequate natural lighting, and phase out low efficiency heating-cooling and electrical home appliances or inefficient means of operating equipment.

In recent years, several countries have developed regulations to increase energy efficiency in buildings and established certification methods that classify buildings with the aim of promoting energy savings. In

Table 1. $\mathrm{CO}_{2}$ emissions Worldwide and in Turkey between 1971 and 2011 (International Energy Agency, 2013)

\section{$\mathrm{CO}_{2}$ Emissions (million tons)}

Year

Worldwide

1971

14.080

Turkey
41.4 (ranked $31^{\text {st }}$ in the world)

\section{1}

31.342

285.7 (ranked $19^{\text {th }}$ in the World)

Table 2. $\mathrm{CO}_{2}$ emission values and ratios Worldwide and in Turkey in 2011 by sector (International Energy Agency, 2013) ${ }^{6}$

\begin{tabular}{|c|c|c|c|c|c|c|c|c|}
\hline \multirow[b]{2}{*}{ Sector } & \multicolumn{8}{|c|}{$\mathrm{CO}_{2}$ Emissions (million tons) and Ratios by Industry (2011) } \\
\hline & Industry & $\%$ & Transport & $\%$ & Residence & $\%$ & Other $^{*}$ & $\%$ \\
\hline Worldwide & 14.336 .1 & 46 & 7.151 .9 & 23 & 5.246 .3 & 17 & 4.608 .0 & 14 \\
\hline Turkey & 120.6 & 42 & 46.1 & 16 & 68.2 & 24 & 50.9 & 18 \\
\hline
\end{tabular}

*Commerce, services, public facility buildings etc.

\footnotetext{
United Nations, 2014, http://www.un.org/climatechange/

International Energy Agency IEA, 2014, http://www.iea.org/topics/ climatechange/
}

\footnotetext{
3 TurkStat, 2012, http://www.turkstat.gov.tr/UstMenu.do?metod=temelist 4 Marks, 1997, s. 332.

5 Turkey Ministry of Energy and Natural Resources, 2010, s. 22.

6 International Energy Agency IEA, 2014, http://www.iea.org/topics/ climatechange/
} 
Turkey, the Energy Efficiency Law Nr. 5627 of 2007 aims to improve efficient use of energy resources with the intention of using energy effectively, preventing waste, easing the economic load of energy costs and protecting the environment. One of the regulations foreseen by this law is the "EPB - The Directive on the Energy Performance of Buildings", which was enacted in European Union states in 2002. In scope of European Union approximation, the most recent version of this regulation was enacted in Turkey in 2010 under the name "EPB - The Regulation on the Energy Performance of Buildings" (published in the National Gazette of the Republic of Turkey on April $\left.1^{\text {st }}, 2010\right)$. The concept of this regulation is to facilitate energy consumption in buildings towards renewable sources of energy. It aims to develop methods to make use of all energy types, classify buildings by $\mathrm{CO}_{2}$ emissions and used energy types, determine minimum energy efficiency methods and apply these methods on existing buildings, and make use of renewable energy sources in new and existing buildings. Besides architectural, mechanical, electrical designs and applications the decrees of the regulation also includes the decision to prepare energy performance certificates for all buildings by 2015 .

The operation of heating, cooling, lighting and other electrical appliances is the source of energy consumption in residential buildings. Residential buildings account for $75 \%$ of buildings in Turkey and the cumulative share of heating-cooling to $75-80 \%$ of household energy consumption while lighting and other electrical appliances account for the remaining 20-25\%. ${ }^{7-9}$ These data display that most of the energy used in residential buildings is to meet heating-cooling requirements. Therefore, solutions that consider renewable energy sources gains significance in the context of improving energy use performances of existing residential buildings' envelope.

The basic objective in increasing energy performance on buildings envelope is to procure energy needs from passive methods that utilise solar and wind power, or otherwise engage active systems. ${ }^{10-12}$ Improvement solutions that determine the efficient use of solar energy will vary based on the architectural characteristics of each building, the character of local urban pattern and local geographical conditions. Considering that heating loads account for a significant part

\footnotetext{
http://www.eie.gov.tr/eie-web/ 9 The World Bank, 2011, s. 32. turkce/en_tasarrufu/konut_ ${ }^{10}$ Yüksek \& Esin, 2011, s. 64 ulas/en_tasarruf_bina_isi.html ${ }^{11}$ Roaf et al., 2007, s. 75.

8 Yumurtacı and Dönmez, 2013, s. ${ }^{12}$ Gowri \& Krishnan, 2004, s. 5640.
}

of energy use in residential buildings, effective utilisation of solar power using direct and indirect methods shall play an important role in balancing energy costs due to a drop in active heating requirements. More so, a significant saving on cooling costs will be possible due to improvement solutions aimed at controlling solar energy. Keeping in mind that existing structures in countries like Turkey are constantly renewed due to reinforcement and improvement work and for aesthetic reasons, such maintenance work and interventions provide opportunities to implement methods that can effectively use the sun light.

\section{Relevant Literature and Aim}

There are sample studies in literature both from Turkey and worldwide by engineers on improvements that reduce heating-cooling energy consumption in buildings that consider mechanical infrastructure, building envelope, building location and environmental data. Yilmaz (2009) studied energy consumption values and $\mathrm{CO}_{2}$ emissions in model buildings and compared specific alternative solutions related to architecture and mechanical infrastructure. Eskin et al. (2007) studied the effects of climatic conditions, thermal insulation, building orientation, exterior colour and window systems on energy consumption. Kılıçıı (2012) studied energy consumption of a sample building and elaborated on improvements that could be made on the building to reduce energy use. In their study Çelik et al. (2011) used the EPB-TR method to determine the heating-cooling energy requirements of a chosen building based on exterior wall heat conductivity, window characteristics and draft rates and presented the effect of these factors on energy savings. Cheung et al. (2004) demonstrated the effects of modifications on the building envelope in order to reduce cooling loads of a high-rise residential building. A 31\% saving was achieved in annual cooling energy consumption by improvements on exterior walls, window characteristics and shading effects. Bektaş (2005) et al. calculated the annual heating energy demand of buildings based on window direction and window types. According to the calculations in the study, heating requirements can be reduced by $20-30 \%$ in cold climates by only installing low-E double-glazing windows instead of single-glazed alternatives. Soysal (2008) calculated the energy consumption values of a sample building using the ECOTECT $5.5 \mathrm{v}$ programme. He also calculated the effects of exterior thermal conductivity coefficients, glass enclosed balconies and the effect of unheated spaces to neighbouring heated spaces. Lam et al. used the DOE programme to calculate and compare the heating-cooling 
energy consumptions of a sample building in various climatic regions of China. Heravi et al. (2014) studied the renewable energy system application and energy performance measures concerned with building design and construction as important effective measures in the developing country of Iran. Yu et al. (2009) analysed the thermal performance of several window systems, including normal windows commonly installed in apartment buildings, super-windows, double-glazed windows, and single- and double-glazed low-e coated windows. They applied the thermal transmittance (U-factor) of the various window systems to current building energy efficiency ratings used in South Korea, and evaluated the effects on building energy efficiency ratings. Yu et al. (2009) studied a new approach for the evaluation of energy and thermal performance of residential envelopes named EETP and defined as the heat transfer rate through building envelope per unit building volume and per unit temperature difference between outdoor and indoor conditions. Hasan (1999) used life-cycle cost analysis to determine optimum insulation thickness. The results showed that savings up to $21 \$ / \mathrm{m}^{2}$ of wall area are possible for rock wool and polystyrene insulation. He determined payback periods of 1-1.7 years for rock wool and 1.3-2.3 years for polystyrene insulation depending on the type of wall structure. Comakli and Yuksel (2003) studied the optimum insulation thickness for the coldest cities in Turkey, and when the optimum insulation thickness was applied, a considerable energy saving of $12.113 \$ / \mathrm{m}^{2}$ of wall was obtained in Erzurum. Ozkan et al. (2011) studied carried out for four degree-day regions of Turkey for various insulation materials, glazing areas, and fuel types; the results have been presented in charts. The rest of this study evaluates the effects of different insulation thicknesses and fuel on fuel consumption and thereby on emissions of pollutants such as $\mathrm{CO}_{2}$ and $\mathrm{SO}_{2}$.

Additionally there are studies conducted in Turkey and worldwide amongst the professions of urban planning and architecture concerning the effect of characteristics of urban form and building typology on heating-cooling energy use and means of improving their performance. During the period between 1994-1999 a number of applications appeared in literature about significant decreases in heating-cooling loads with intelligent sizing based on the building envelope direction (with the help of greenhouse with controlled sunlight). ${ }^{13}$ These studies are significant due to the fact that improving the heating-cooling en-

\footnotetext{
${ }^{13}$ Kerestecioğlu et al., 1999, s. 91.
}

ergy consumption performance in residential buildings and those that serve other functions begin with and/ or is closely associated with decisions at a settlement scale. ${ }^{14}$ Terecia et al. (2013) evaluated the impacts of urban configurations, building typology and building standards on energy consumption. According to their study, site density and building envelope properties have a significant effect on the energy performance of the settlement and should be carefully analysed in the urban design process. Compagnon's (2004) results obtained in his project have shown that the solar and daylight availability in dense urban areas is significant even without special planning measures regarding this issue. However, when care is taken, solar and daylight availability can certainly be increased further even for denser urban areas. This method is expected to provide more detailed knowledge about how to plan effective solar cities. Knowles (2003) investigates the resulting interstitial space of the solar envelope that allows a building to change, decay, and move or disassemble in response to the seasons. While solar access zoning typically provides only a fixed image of the city, the interstitium allows architects to conceive a kinetic landscape driven by the rhythms of nature. In the reference case study of Ferrante and Cascella (2011), the concurrence of building type, envelope features, selected passive tools for energy save and plants systems for energy micro-generation from renewable energy sources aims to achieve multi-purpose objectives within a same building frame.

There are studies in Turkey that have been conducted in scope of the EPB - The Regulation on the Energy Performance of Buildings. For instance, the scope of Güçyeter and Günaydın (2012)'s study yield shortcomings; solely dealing with energy-efficient improvement of building envelope, since it is a single aspect of energy-efficiency in buildings. However, other energy consumption end-uses in a building such as artificial lighting, mechanical ventilation, heating and cooling installations may be subject to retrofitting improvements to promote the obtained efficiency due to envelope retrofits. In particular, implementing building integrated renewable energy technologies to existing buildings may be subject to further research and evaluation. With all these aspects integrated, a more holistic perspective can be valuated via calibrated simulation approach. Kazanasmaz et al. (2014) aimed to determine heating energy performance of residential

\footnotetext{
${ }^{14}$ Carbon emissions from fossil fuel use are one of the main reasons of pollution and climate change. The drive to find a solution to this problem has led to the development of evaluation systems that contain principles at the building and settlement levels.
} 
buildings in Izmir in Turkey, regarding the ratio of window and wall areas to external surface area.

With regard to these studies investigating improvements aimed at reducing heating-cooling loads and increasing energy performance in existing buildings, it can be seen that calculations have been developed which consider variables focusing on the relations between building envelope and urban form. Whereas, the objective of this study is to:

- reduce heating-cooling energy consumption (except lighting),

- reduce heating related natural gas bills,

- reduce cooling related electricity bills,

- reduce heating-cooling related $\mathrm{CO}_{2}$ emissions,

by increasing solar energy use capacity in existing residential buildings in the Beykoz District by means of intervening with variables including window areas, window awnings, window characteristics, exterior wall insulation thickness, draft prevention, shading and landscaping elements (blinds, trees, ...).

\section{A Brief Description of Research, Case Study and Methodology}

Beykoz District is located on the north part of Anatolian Istanbul. The district, which is confined by the Black Sea from the North and the Bosporus from the west, consists of a rugged terrain that can reach up to $270 \mathrm{~m}$. featuring several valleys and ridges of varied size rivers like Riva and Göksu. While some of the valleys open up to the Black Sea on a northern axis, others extend on the southwest and west axes, concluding at the Bosporus. Being at the convergence of Mediterranean and Black Sea climates, Beykoz District shows the traits of a transition zone. Therefore summers are not as hot as the Mediterranean climate, nor as rainy as the Black Sea climate.

Beykoz District is economically dependent on fishing, agriculture and forestry, and has been used for recreational purposes since the Byzantine and Ottoman times. Parallel to the development of sea transportation in Istanbul in the second half of $19^{\text {th }}$ century, the district, particularly the Bosporus coastline, became popular amongst high-income groups of the city leading to the addition of two and three storey wooden or stone waterfront mansions and pavilions to the traditional urban pattern. Today these residential neighbourhoods are regarded in the context of urban heritage sites. Beykoz also became one of Istanbul's largest migrant-magnet districts after tanning, leather and shoemaking factories in the early $19^{\text {th }}$ century, and glass factories in the first half of the $20^{\text {th }}$ century that chose to locate along the Bosporus coastline. This activity led to the emergence of pockets of poorly constructed illegal housing, mostly on public lands like forests, in valleys and on slopes behind the industrial facilities lined along the Bosporus. These pockets have continued to grow rapidly until today. During the 1970's three to five storey reinforced concrete cooperative residential buildings were built in and around urban heritage sites such as Anadoluhisarı and Kanlıca. The number of stories increased to five or six during the 1980 's. For reasons such as its proximity to Istanbul, rich nature and recreational potential, Beykoz became an attractive district for secondary residences on the Black Sea coastline and luxury duplex residences with gardens in the areas above the Bosporus hills, after the 1990's.

For the first phase of the field study and with consideration to the brief historical timeline mentioned above, the residential areas in Beykoz District were classified in four groups. These are; urban heritage site, rural, residential area with planning permit (owing legal status) and high-income group residential areas. In the second phase, in order to study natural gas and electricity consumption for heating-cooling purposes and $\mathrm{CO}_{2}$ emissions in residential buildings in the district, we selected a sample settlement and residential building that would represent four different residential patterns and allow generalisation for residential pattern of similar characteristics (Table 3 ). We made sure that the sample residential buildings within the identified settlements had planning permits. At this stage, historic waterfront mansions and pavilions were excluded from the study because it was impossible to make general assumptions due to the fact that these buildings have different structural details and specific solution proposals.

In the third stage of the field study, the following has been performed on the residential buildings mentioned in Table 3;

Table 3. General information about the selected building in Kanlıca for heating-cooling calculations

Settlement/neighbourhood

Kanlıca

Characteristic of residential pattern

Type of residence

Urban heritage site

Number of storeys Multiple family

Construction system 3 storeys + basement RF concrete 
- preparation of layout plan showing external factors and elements (building location, orientation, other buildings and trees) that play a role in energy gain and loss,

- drawing of plan, view and sections,

- calculations and profiling of exterior wall area, window area,

- determining roof type, flooring type characteristics and drawing of sections.

The subsequent stages of the field study included calculating current heating and cooling energy consumption of the sample residential buildings in the Beykoz District. Energy consumption was recalculated based on specific improvements in order to obtain comparative results. Accordingly, the following was calculated for the selected four residential buildings in the fourth stage of the field study (with consideration to residential building's plan, section, relation with surrounding buildings and window surface areas):

- Calorific energy demand and cost calculation according to ASHRAE (American Society of Heating, Refrigerating and Air Conditioning Engineers) Standards.

- Solar access analysis was prepared for the selected residential buildings in order to perform evaluations on Ecotect and Integrated Environmental Solution programmes.

- The heating-cooling energy consumption of the selected residential buildings was calculated using the IES $<V E>$ "Integrated Environmental Solution $<$ Virtual Environment>" simulation programme.

Heating and cooling load calculation refers to the amount of energy required to keep the building in desired temperature and humidity. Heating and cooling accounts are determined by the lighting in the indoor and outdoor conditions, the amount of heat emitted by humans and used equipment. In this study, annual heating and cooling energy consumption of buildings were performed by hourly heat load calculations. Building as a whole is discussed in this calculation by considering the indoor temperature as $24^{\circ} \mathrm{C}$ and relative humidity $65 \%-50 \%$ for the summer months while $20^{\circ} \mathrm{C}$ and $30 \%$ relative humidity for winter months. For the ambient temperature the measured values with data logger and thermocouple are used.

The annual heating load of the building are calculated by subtracting the sum of solar heat gains and internal heat gains that are measured on an hourly basis from the sum of heat loss and air leakage that occurs through the transmission. Formulas 1 and 2 are used to calculate the heat loss given below;

\begin{tabular}{|c|c|}
\hline \\
\hline \multicolumn{2}{|l|}{$\begin{array}{l}Q_{\text {cond }}=U \times A x \Delta T(W) \\
Q_{\text {inf }}=\rho . c . n h \text { Vh. } \Delta T\end{array}$} \\
\hline$\rho:$ density of air, & $\left(\mathrm{kg} / \mathrm{m}^{3}\right)$ \\
\hline c: specific heat of air, & $(J / k g K)$ \\
\hline$n_{h}:$ the number of changes in air, & $\left(h^{-1}\right)$ \\
\hline$V_{h}:$ ventilated volume, ( $\left.\mathrm{Vh}=0,8 \mathrm{Vbrüt}\right)$, & $\left(m^{3}\right)$ \\
\hline$U:$ the overall heat transfer coefficient & $(\mathrm{W} / \mathrm{m} 2 \mathrm{~K}$ \\
\hline : heat transfer surface area & $\left(m^{2}\right)$ \\
\hline
\end{tabular}

For natural ventilation in buildings, $n_{h}=1,0 h^{-1}$ value is used in case of using the window systems of the companies that have granted the certificate of national or international authority conformity.

ASHRAE thermal balance method is used to calculate the cooling loads. Thermal equilibrium method allows detailed simulations for the surface temperature and heat flow. Thermal equilibrium is a calculation method which is closest to the actual that takes the heat transfer balance occurs through transmission surface, convection, radiation and other heat loads in the room into account. In this study, the heat gain through glass from solar radiation, the heat gain transmitted from exterior walls, the windows and roof, the heat gain from lighting, devices and human are calculated hourly. Hourly heat from solar radiation gain is calculated based on according to data from Istanbul and windows' directions. The transmitted solar radiation gain is calculated by multiplying SHGC value and the area of a window as given in the formula 3 .

$$
\mathrm{Q}_{\mathrm{rad}}=\mathrm{E}_{\mathrm{t}} \times \mathrm{A}_{\mathrm{cam}} \times \mathrm{SHGC}(\mathrm{W})
$$

$E\left(w / m^{2}\right)$ : Heat from solar radiation according to direction

SHGC (without a unit): Solar heat gain coefficient

The heat gain transmitted from the window surface is calculated in the formula 4.

$\mathrm{Q}_{\text {cond }}=\mathrm{U}_{\text {cam }} \times \mathrm{A}_{\text {cam }} \times \Delta \mathrm{T}(\mathrm{W})$

In Table 4 the solar radiation intensity values used for the province of Istanbul and the values from Carrier HAP 4.60 software are given.

In the calculation of heat gain accounts from human the values given in Table 5 is used.

Heat emitted by armatures used in lighting the room units, is an important factor in the cooling account. Heat gains from lighting vary according to armature types. Heat produced by incandescent lamps 
Table 4. Solar radiation values by direction

\begin{tabular}{llcc}
\hline Direction & Month & Hour & Radiation intensity $\left(\mathbf{W} / \mathbf{m}^{\mathbf{2}}\right)$ \\
\hline North & August & 12.00 & 110.5 \\
South & August & 12.00 & 479.5 \\
East & August & 08.00 & 669.3 \\
West & August & 16.00 & 670.7 \\
Horizontal & August & 13.00 & 767.2 \\
\hline
\end{tabular}

Table 5. Radiated heat gain from people (ASHRE)

\begin{tabular}{lcc}
\hline Level of activity & Sensible Heat (W) & Latent Heat (W) \\
\hline Rest and light work & 70 & 45 \\
Heavy work & 170 & 255 \\
Fitness & 210 & 315 \\
\hline
\end{tabular}

Table 6. Information about the selected existing residential building in Kanlıca

\begin{tabular}{ll} 
Building Information & \\
Location & Istanbul, Kanlica \\
Longitude, Latitude, Elevation & $40,97 \mathrm{North}, 28,82$ East, $37 \mathrm{~m}$ \\
Net Area of Building & $957 \mathrm{~m}^{2}$ \\
Number of Storeys & $2 \mathrm{Normal}, 1$ Ground, 1 Basement \\
UDD & $0.61 \mathrm{~W} / \mathrm{m}^{2} \mathrm{~K}$ \\
UP & $2.5 \mathrm{~W} / \mathrm{m}^{2} \mathrm{~K}$ \\
Uta & $0.65 \mathrm{~W} / \mathrm{m}^{2} \mathrm{~K}$ \\
Uds & $3.29 \mathrm{~W} / \mathrm{m}^{2} \mathrm{~K}$ \\
SHGCWindow & 0.75 \\
Calculation Assumptions & \\
Lighting Power Shop & $30 \mathrm{~W} / \mathrm{m}^{2}$ \\
Lighting Power Residence & $15 \mathrm{~W} / \mathrm{m}^{2}$ \\
Number of People Shop & $10 \mathrm{persons}$ \\
Number of People Residence & $8 \mathrm{persons}$ \\
Summer Draft Coefficient & $0.25 \mathrm{Ach}$ \\
Winter Draft Coefficient & $0.5 \mathrm{Ach}$ \\
Noticeable Heat Gain per Person & $75 \mathrm{~W}$ \\
Latent Heat Gain per Person & $55 \mathrm{~W}$ \\
Indoor Summer Temperature & $24{ }^{\circ} \mathrm{C}$ \\
Indoor Winter Temperature & $20^{\circ} \mathrm{C}$ \\
Outdoor Weather Information & $33^{\circ} \mathrm{C}$ \\
Summer DBT Temperature & $22^{\circ} \mathrm{C}$ \\
Summer WBT Temperature & $-2.6^{\circ} \mathrm{C}$ \\
Winter Design Temperature DBT & \\
& \\
\hline
\end{tabular}

UDD: External wall heat transfer coefficient (W/ $\left.\mathrm{m}^{2} \mathrm{~K}\right)$; UP: Window heat transfer coefficient $\left(\mathrm{W} / \mathrm{m}^{2} \mathrm{~K}\right)$; UT: Ceiling heat transfer coefficient $\left(\mathrm{W} / \mathrm{m}^{2} \mathrm{~K}\right)$; Uds: Floor heat transfer coefficient (W/ $\left./ \mathrm{m}^{2} \mathrm{~K}\right)$; SHGC: Solar heat gain coefficient; DBT: Dry bulb temperature; WBT: Wet bulb temperature.

is more than electronic ballast (current limiter) armatures. Heat gains from lighting are calculated by using the intensity illuminations given in Table 6 and according to armatures types. 


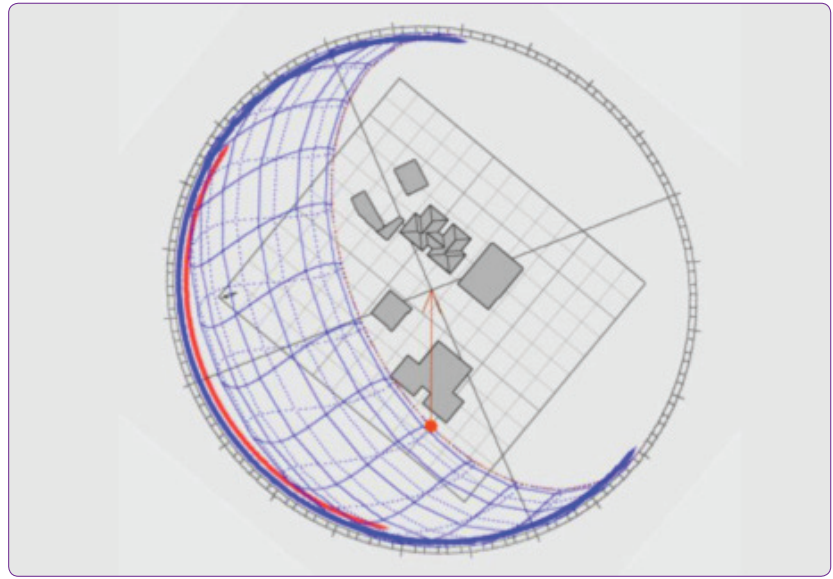

Figure 1. Orientation of the building in Kanlıca (A building's orientation and relation to others plays an important role in its insolation characteristics).

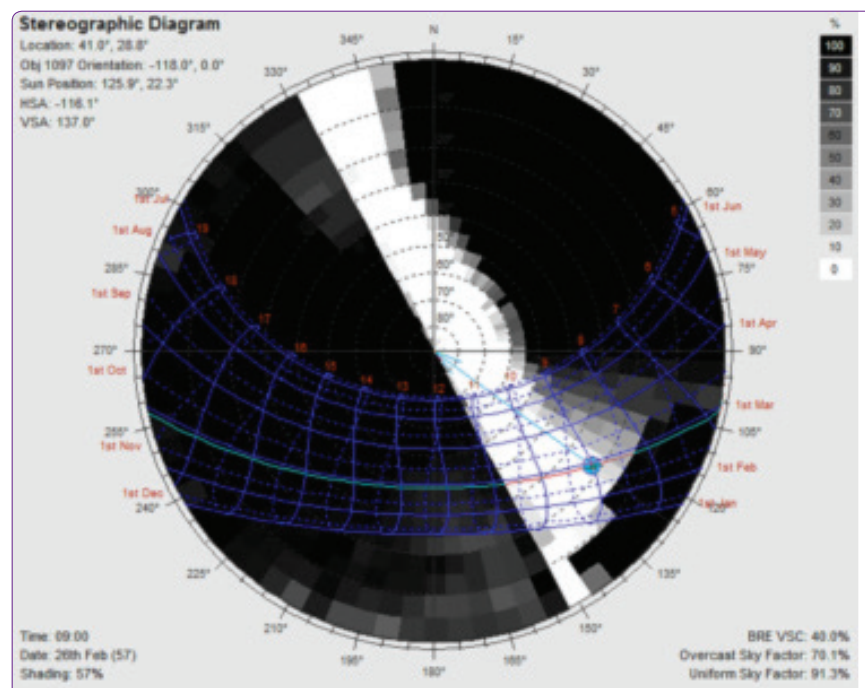

Ground Floor-1 EAST

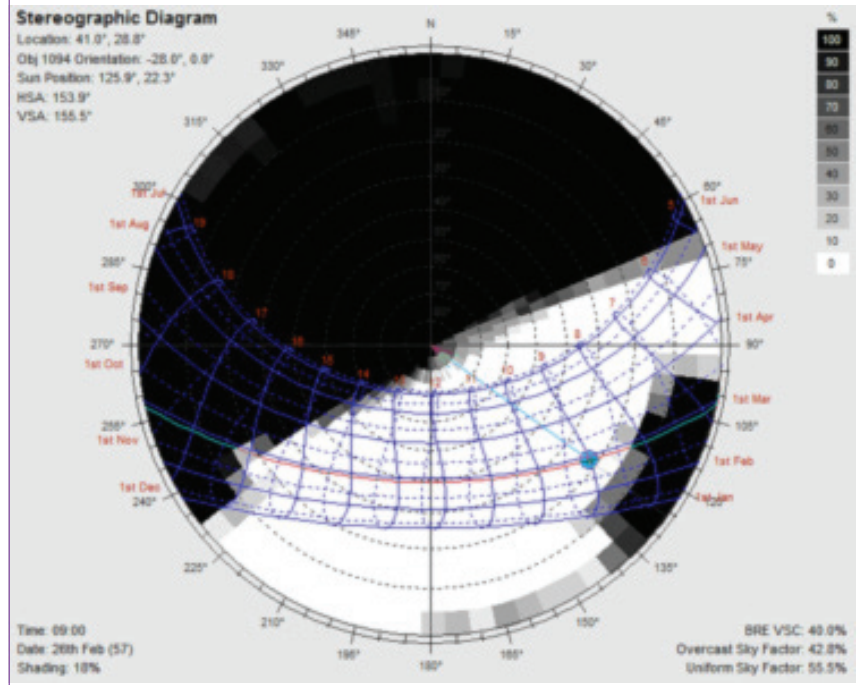

Ground Floor-SOUTH
The insolation in the selected building is analysed with the Ecotect programme by using sun path diagrams and shadow diagrams. The shadings of the building on 21 December ve July per a day is given in Figure 1-5. As it is perceived from these figures, the east and west facades of the building mostly remain in the shadow of neighbouring buildings. On the other hand while the south façade of the building partly remain in the shadow during the winter period, because of the direct sun radiations on the ground, neighbouring buildings do not have any effect during the summer period. Accordingly, $50 \mathrm{~cm}, 1 \mathrm{~m}$ and $1.5 \mathrm{~m}$ sun breaker analyses were performed on the south side of the building. In order to optimise winter and summer heat gains $1 \mathrm{~m}$ awnings on the south side of the building were proposed as a solution due to consistency

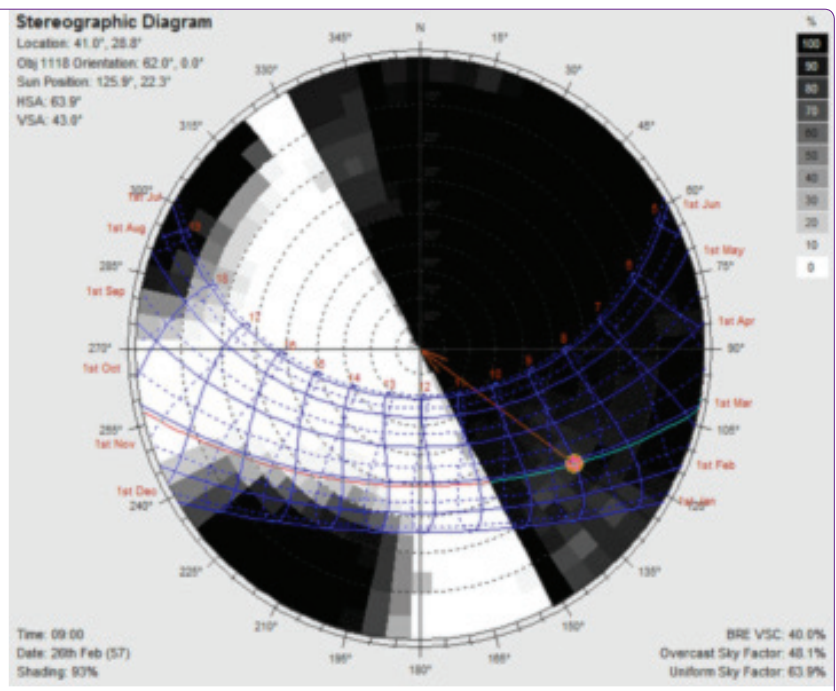

Ground Floor-WEST

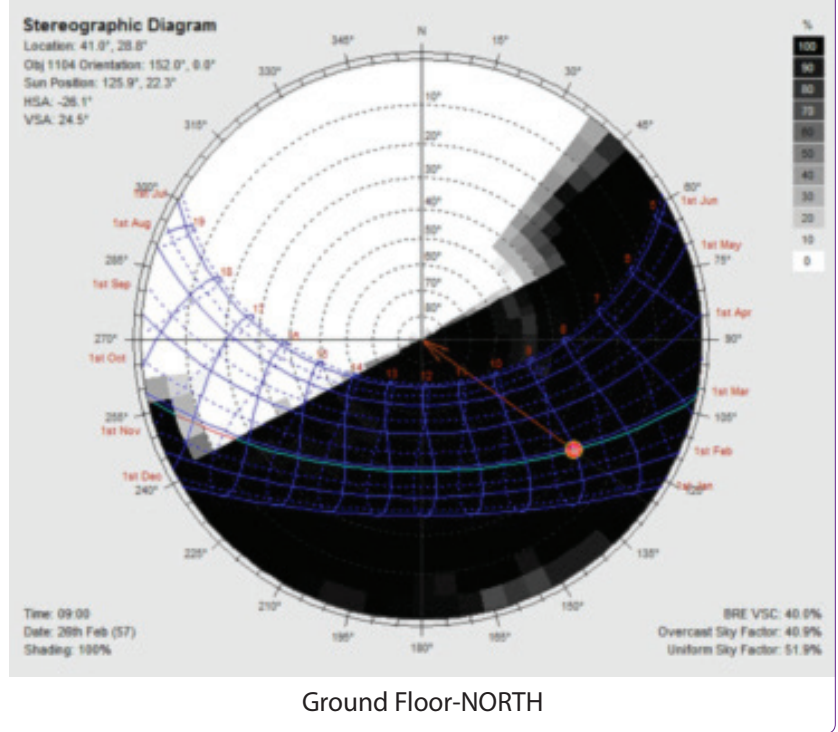

Figure 2. Sun path diagram showing the insolation times and value for the ground floor. 


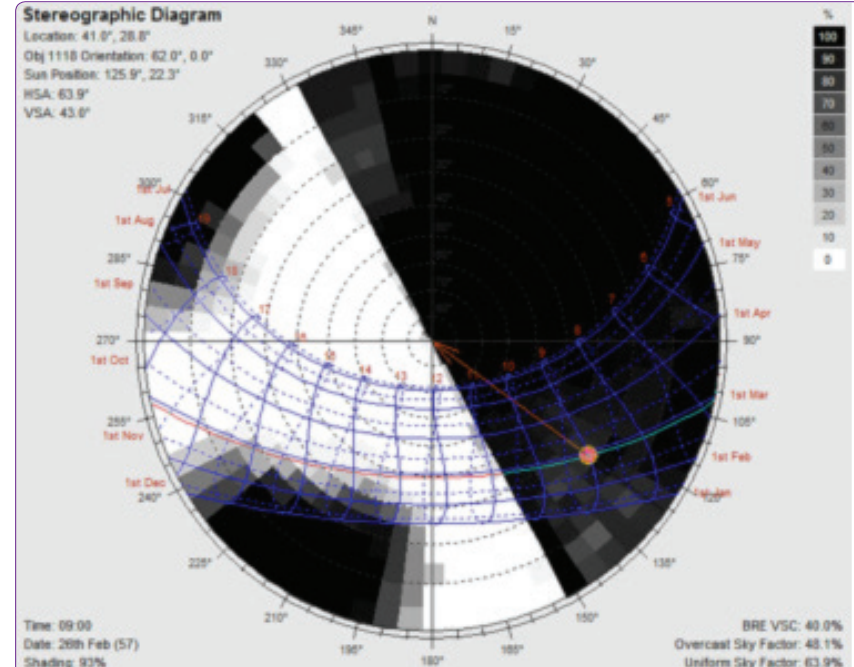

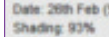

$1^{\text {st }}$ Floor-WEST

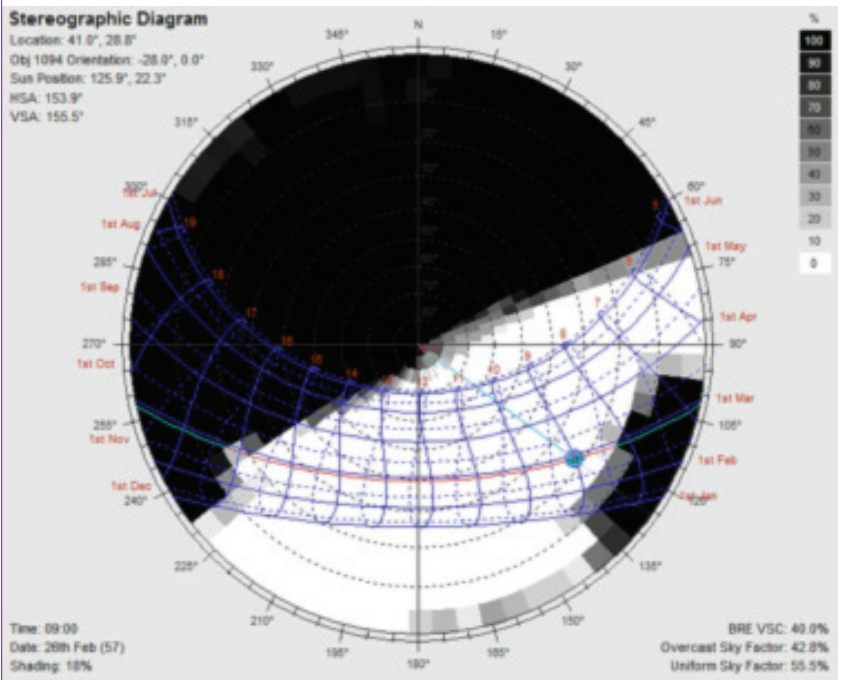

$1^{\text {st }}$ Floor-SOUTH A

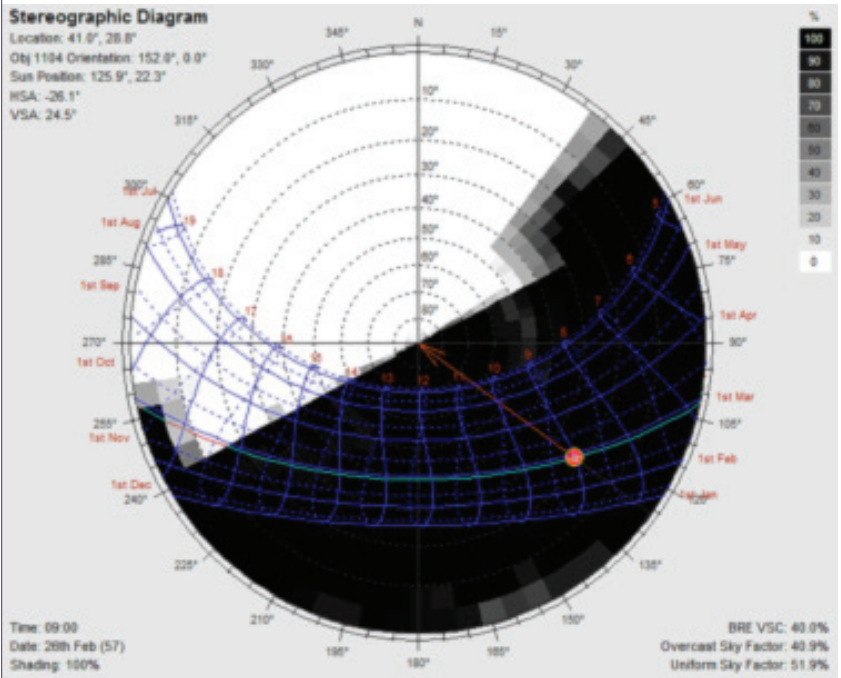

$1^{\text {st }}$ Floor NORTH A

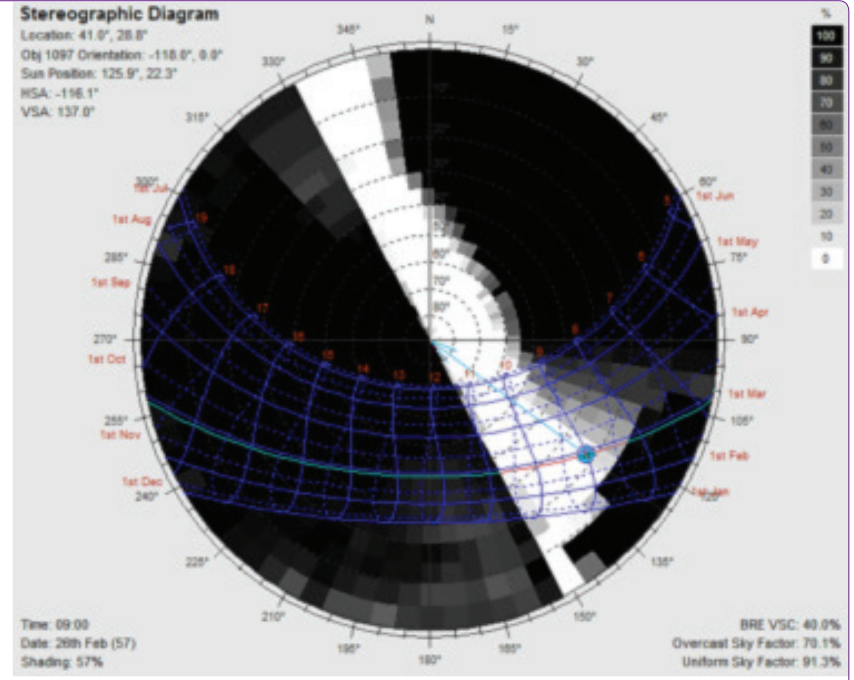

$1^{\text {st }}$ Floor-EAST

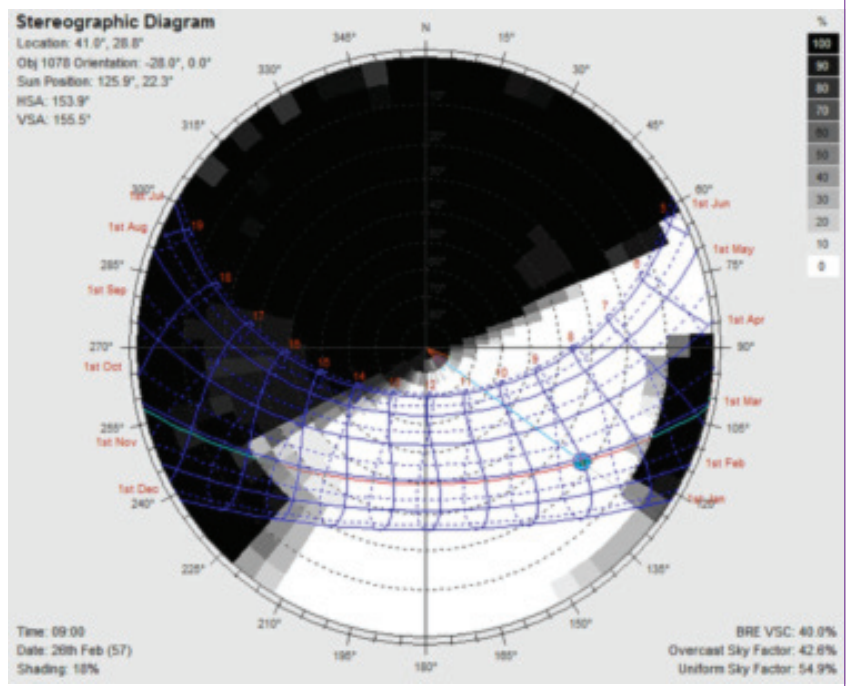

$1^{\text {st }}$ Floor-SOUTH B

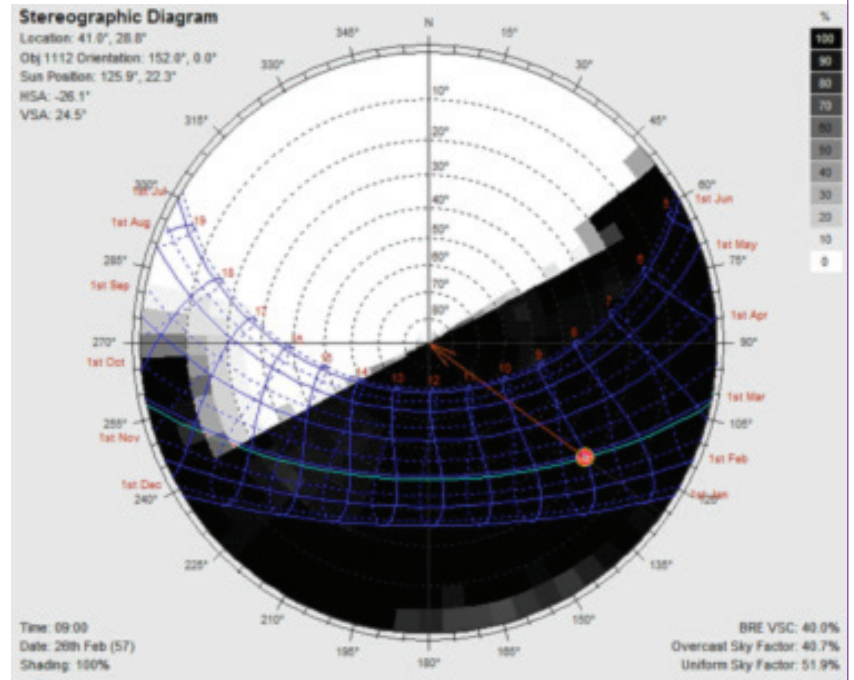

$1^{\text {st }}$ Floor-NORTH B

Figure 3. Sun path diagrams showing insolation times and values for the first floor of the building. 


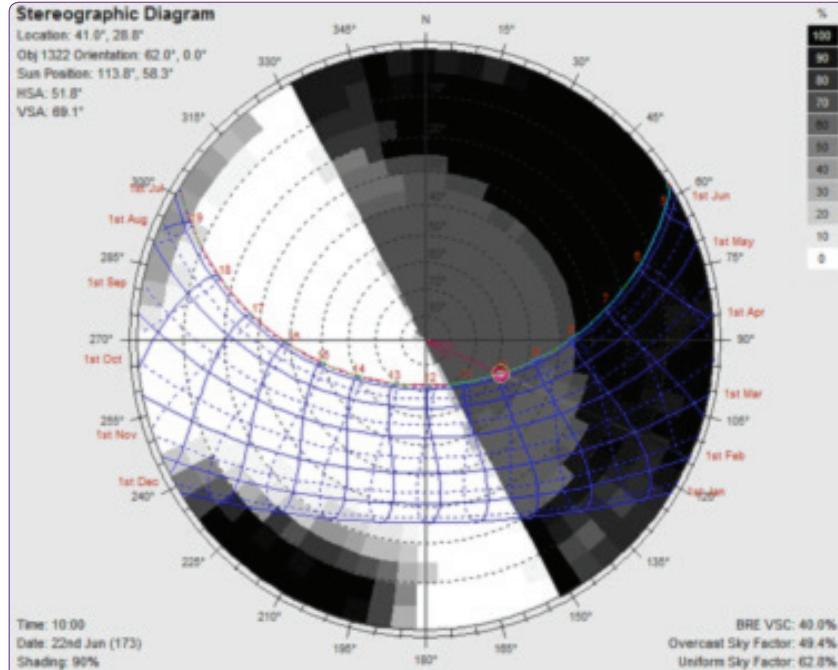

$2^{\text {nd }}$ Floor-WEST

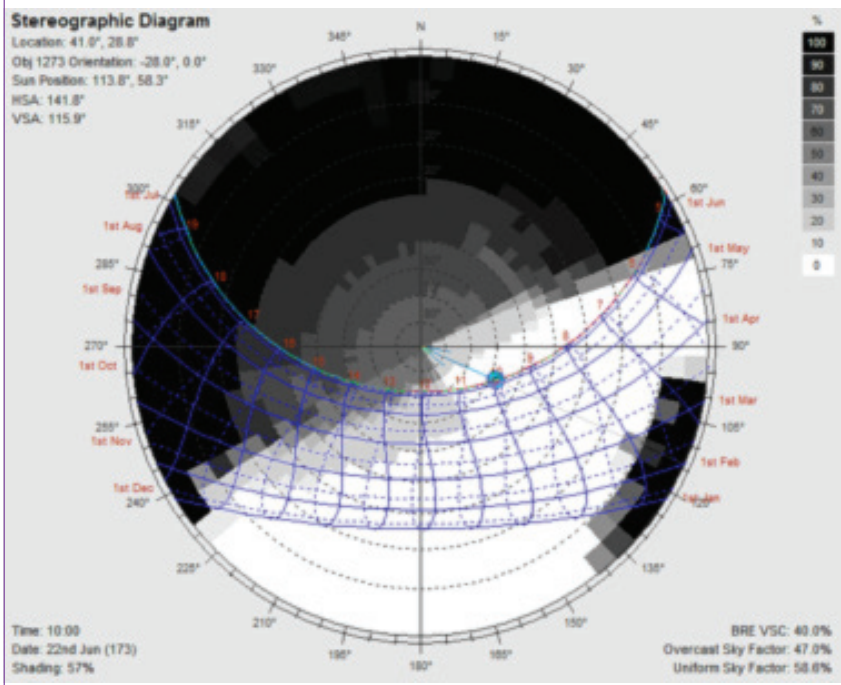

$2^{\text {nd }}$ Floor-SOUTH A

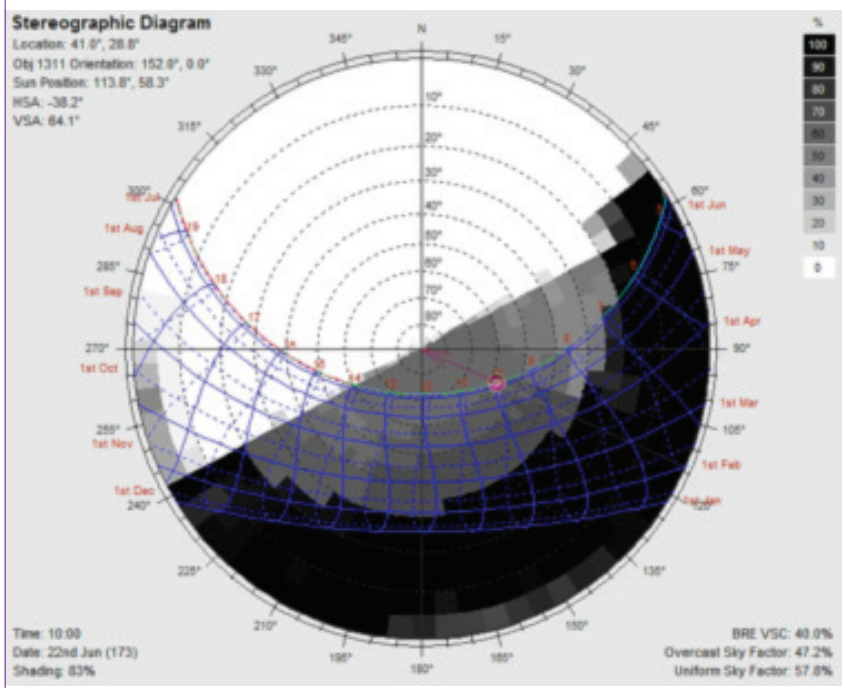

$2^{\text {nd }}$ Floor-NORTH

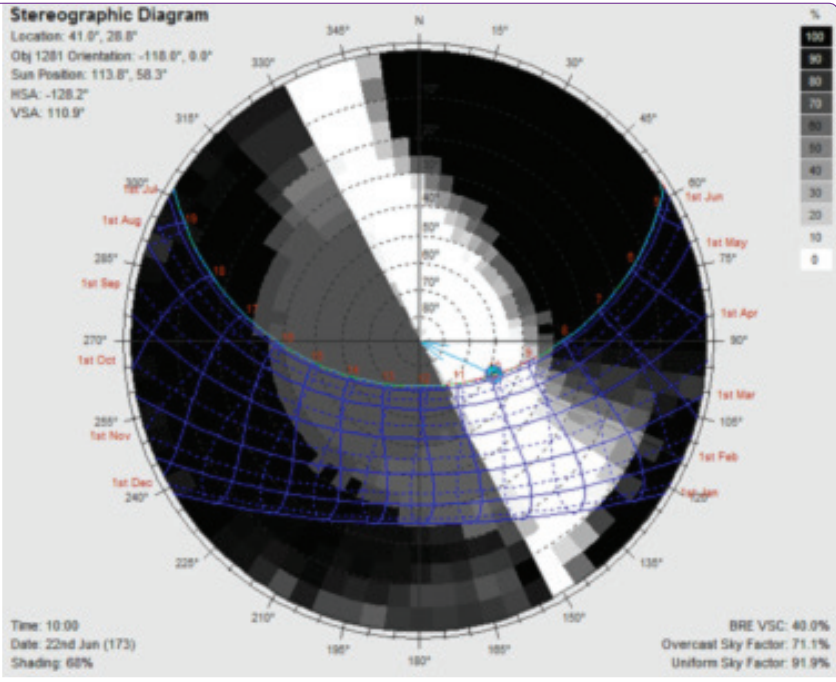

$2^{\text {nd }}$ Floor-EAST

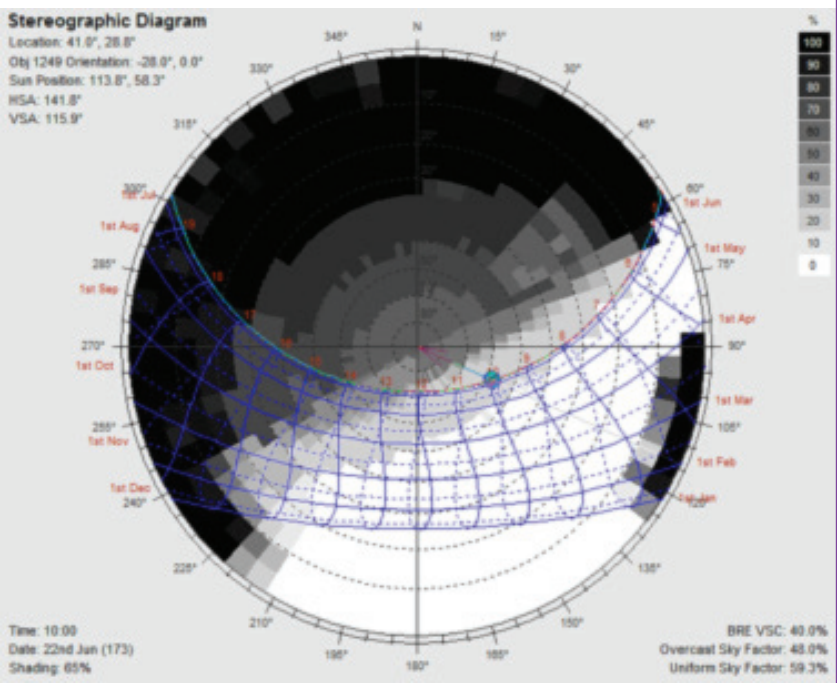

$2^{\text {nd }}$ Floor-SOUTH B

Figure 4. Sun path diagrams showing insolation times and values for the second floor of the building. 


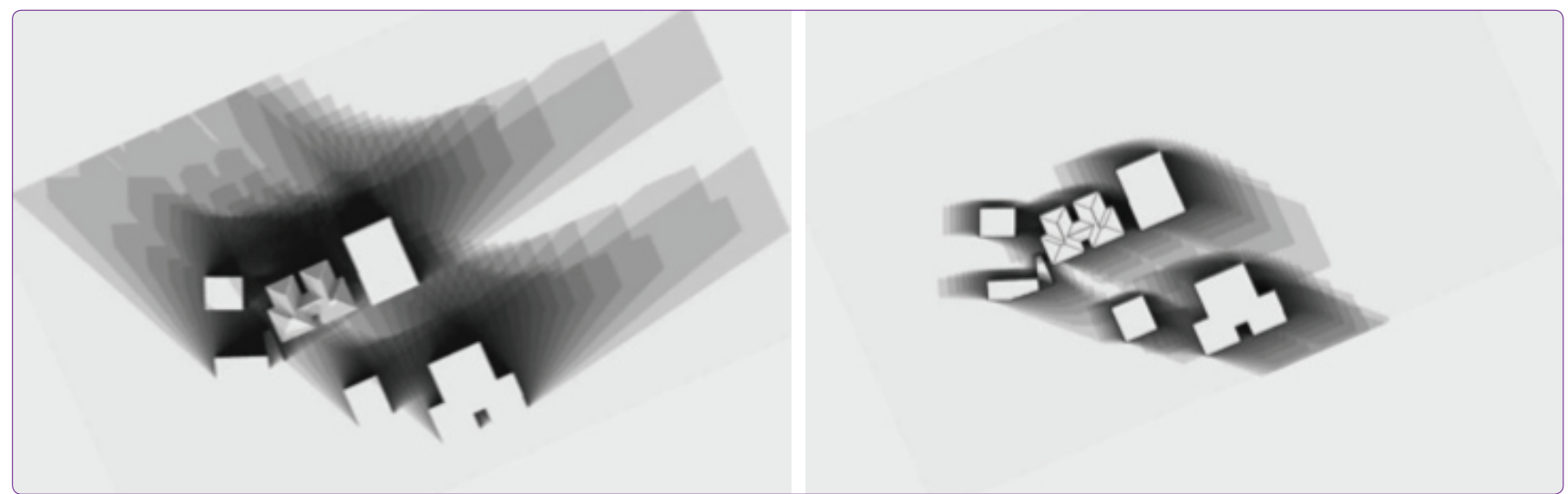

Figure 5. Shading diagrams, 21 December (left) and 21 June (right).

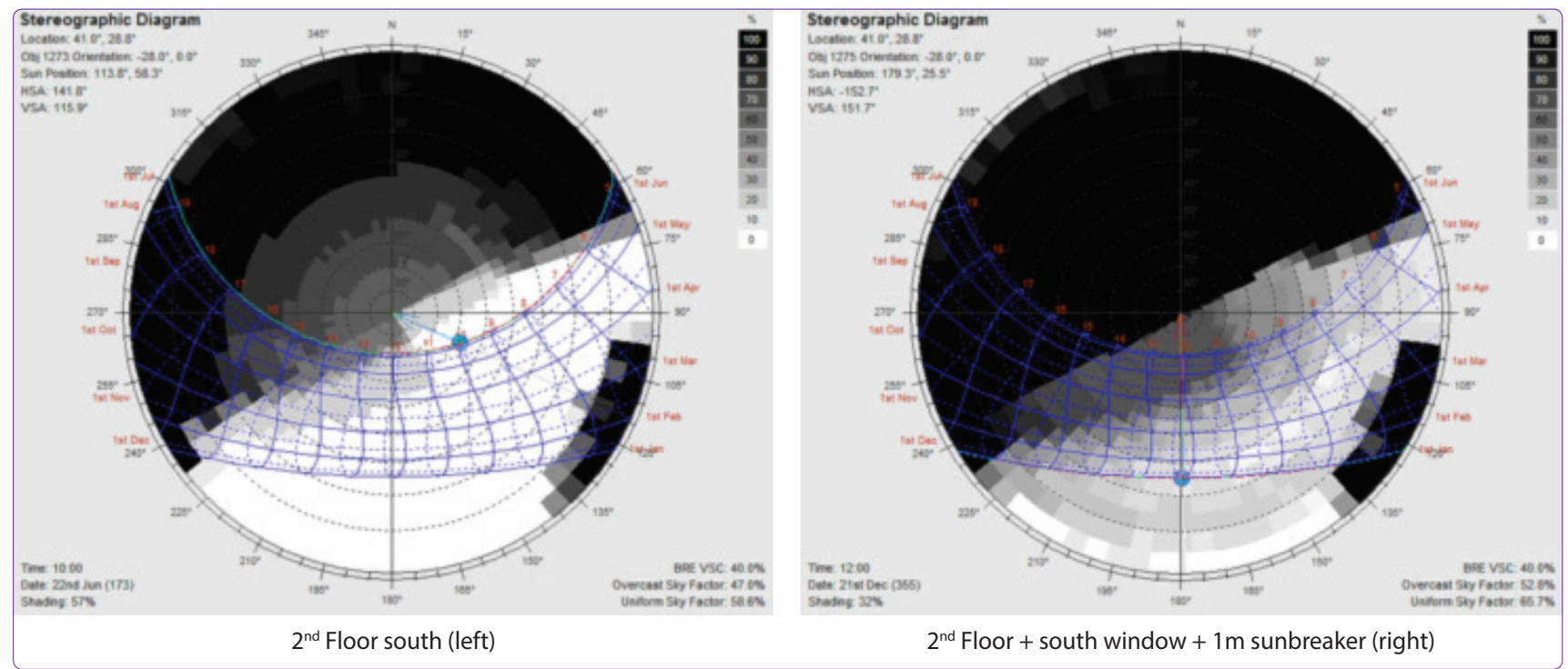

Figure 6. Sun path diagrams showing insolation on the $2^{\text {nd }}$ storey and the protective difference with $1 \mathrm{~m}$ awnings.

with the architectural identity of Beykoz District (Figure 6). In this study it is clear that, the maximum solar radiation rate is received on the first and second floors of the building facade. Hence, the sun breaks were studied on the both floors and window shade option's lengths are determined as $0.50 \mathrm{~m}, 1 \mathrm{~m}$. and $1.5 \mathrm{~m}$. It is examined that while $1.5 \mathrm{~m}$ window shade prevent necessary sun radiation during the winter period, the window shade with a $0.50 \mathrm{~m}$ length does not provide effective shading. Therefore, $1.00 \mathrm{~m}$ window shades provide optimum solution for heating and cooling loads for the building. Insolation and shading by the external elements were included in the calculations using the IES $<\mathrm{VE}>$ "Integrated Environmental Solution $<$ Virtual Environment $>$ " simulation programme.

A datalogger device was used to constantly measure interior and exterior surface temperatures for each side of the existing building in Kanlıca. During the measurements, the testo 176 T4-type brand is used a total of 4 , including 1 for every aspect of the external sensor connected to 4-channel temperature data logger. The equipment has a storage capacity of two million data and work in -20 to $+70^{\circ} \mathrm{C}$ temperature range.

According to the measurements, the coldest day was January $10^{\text {th }}, 2012$ and the hottest day was August $18^{\text {th }}, 2013$. Measurements on those dates have been presented in the graphs below (Figure 7-10). Wall temperature values were used for the building's heat loss and heat gain calculations. Heating system was working thermostatically controlled; and the thermostat is set at $20^{\circ} \mathrm{C}$ as can be follow in the figures 9 and 10 .

Heating-cooling load calculations reflect the energy needed to keep the building at desired temperature and humidity with regard to human comfort standards. Heating-cooling calculations are made accord- 


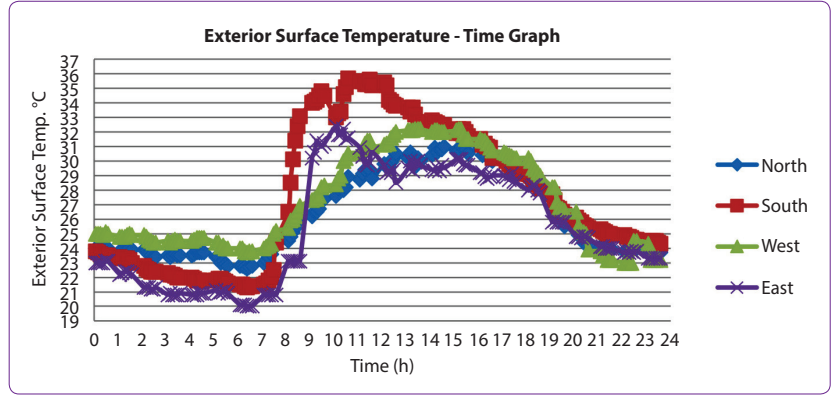

Figure 7. Exterior wall, exterior surface temperatures on the building in Kanlıca for each direction on the hottest day of the year (August 18 ${ }^{\text {th }}$ ).

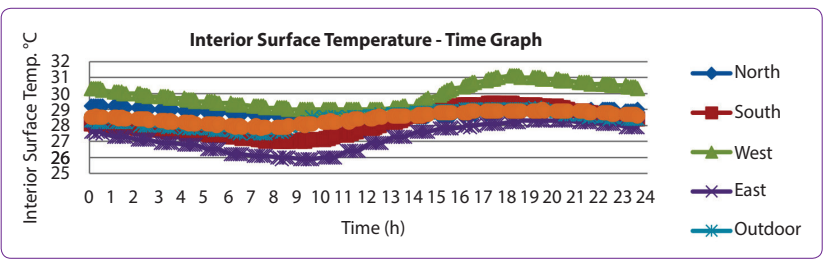

Figure 8. Exterior wall, interior surface temperatures for each direction on the hottest day of the year (August $18^{\text {th }}$ ).

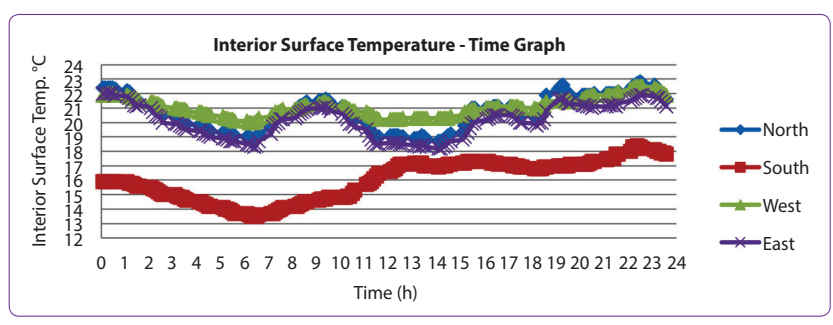

Figure 9. Exterior wall, interior surface temperatures for each direction on the coldest day of 2013 (January $10^{\text {th }}$ ).

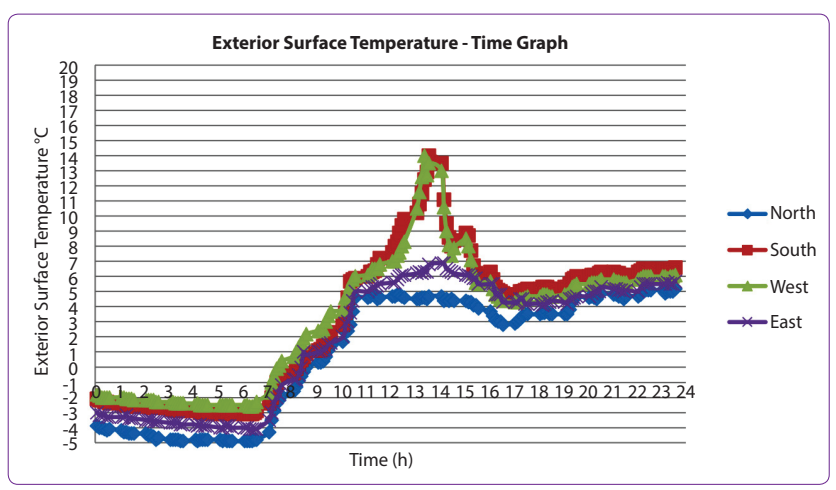

Figure 10. Exterior wall, exterior surface temperatures for each direction on the coldest day of 2013 (January 10 $10^{\text {th }}$ ).

ing to outdoor weather conditions, and heat emitted from lighting, humans and equipment/machinery inside the building. Table 6 presents parameters and values used in this study to calculate heating-cooling energy demand of the residential building in Kanlıca.

In the forthcoming stages of the study, heating- cooling energy consumption is recalculated based on the specific improvements in order to increase the efficiency of energy use in the existing residential building. Accordingly, the current and improved energy consumption comparison for the selected residential buildings in the Beykoz District is performed to demonstrate the achieved energy gains in the outcome section of the paper.

\section{Improvements For The Selected Residential Building in Kanlıca}

This section initially provides information about the urban pattern, external elements and architecture in the selected existing residential building located in Kanlıca. It has two storeys, excluding basement. This reinforced concrete building is situated on the basin of a valley that opens out to Bosporus in the west. It is oriented to southwest. The building is surrounded by detached and attached buildings and has two singlestorey buildings and deciduous trees on the southwest. There are more deciduous trees on the northwest side and a five-storey residential building on the northeast side of the building. The southeast side overlook a road that provides access to the building (Figure 11).

In order to minimise energy consumption the following itemised improvement interventions have been defined for the selected residential building and heating-cooling energy consumption calculations have been performed accordingly.

1. Smart window rate has been applied for heat gains and losses on the building envelope. The objective of this improvement is to maximise daylight use and minimise electricity consumption. According to the current and improved values provided in Table 7, window area on the south facade of the residential building have been increased by $13 \%$ to allow maximum daylight, meanwhile window area on the northern facade has been decreased by $16 \%$ in order to reduce heat loss.

2. Triple-glazed, Low-E film windows have been used to reduce the heat transmission coefficients. Method of reducing the value for the windows are specified to use triple-glazed and to apply low-emissivity coatings on the inner surface of the windows instead of double glazed windows. Low-emissivity coatings are defined as Low-E window glass. Low-E windows improve the overall heat transmission coefficient that gives the glass back to its high reflectivity. The combination selected from the manufacturer catalogs, 


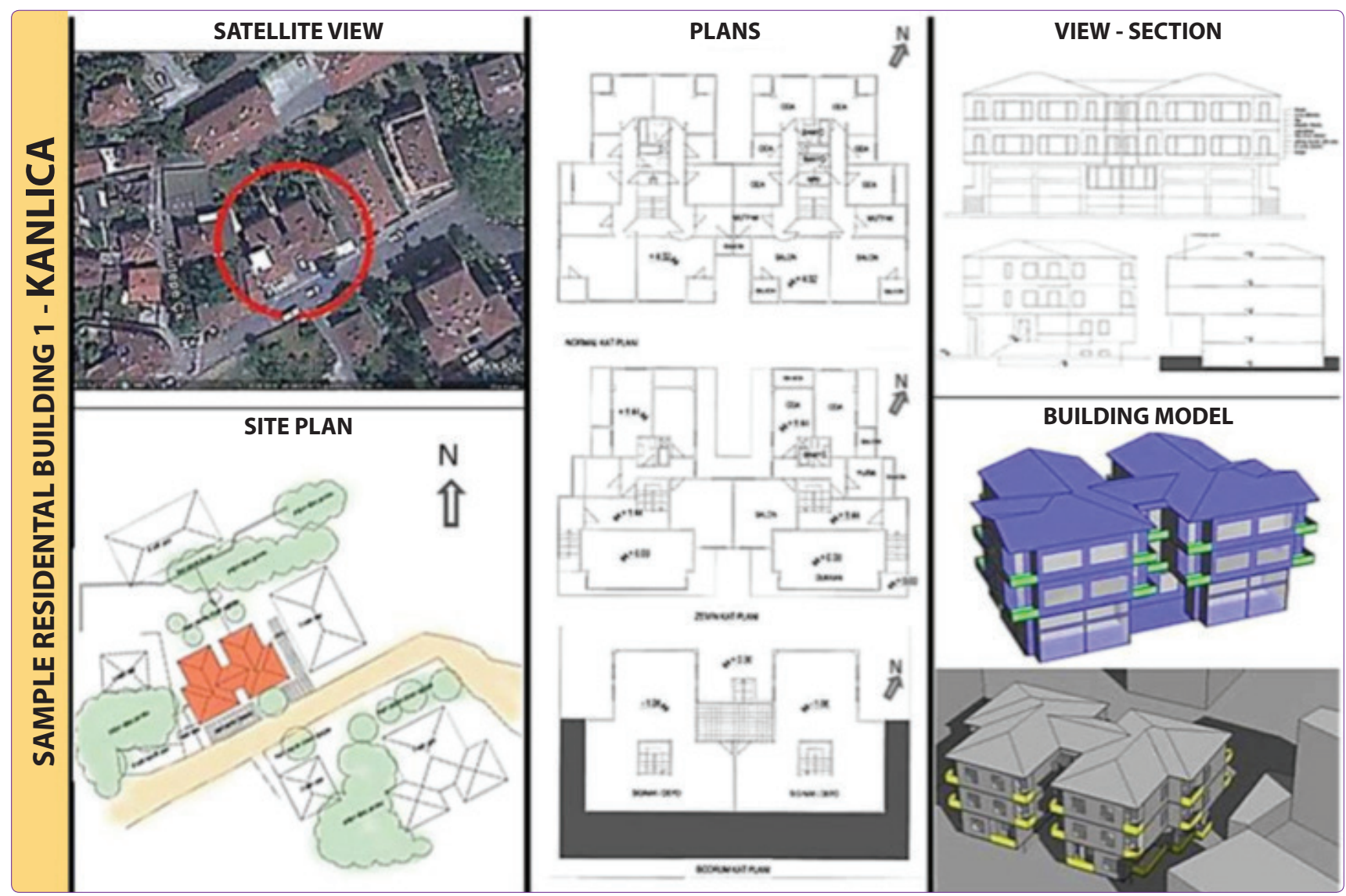

Figure 11. The location and architectural drawing of existing building in Kanlıca.

the thickness of internal and external surfaces of the insulating glass is $4 \mathrm{~mm}$ Low E glass, while medium colorless glass is $4 \mathrm{~mm}$ float glass. In the spaces between the first and second $16 \mathrm{~mm}$ there is argon gas. Accordingly, while UP $=2.5 \mathrm{~W} / \mathrm{m}^{2 \circ} \mathrm{K}$, SHGCWindow $=0.75$ is applicable in the existing building, UP $=0.9 \mathrm{~W} / \mathrm{m}^{20} \mathrm{~K}$ ve SHGCWindow $=0.48$ is considered for the renew building.

3. The exterior envelope of renew building was designed to provide optimum thermal insulation. Therefore, heat transfer was minimised in both directions. The EPS insulation thickness on the exterior wall of the building was increased from
$3 \mathrm{~cm}$ to $8 \mathrm{~cm}$. Currently, the exterior wall UDD value for the building was $0.61 \mathrm{~W} / \mathrm{m}^{2} \mathrm{~K}$. After the improvements, exterior wall UDD has been calculated as $0.35 \mathrm{~W} / \mathrm{m}^{2} \mathrm{~K}$ (Figure 12,13$)$.

4. Insulation has been installed on the flooring of unheated spaces in the building. Just as, there is an unheated basement floor. For that, $2 \mathrm{~cm}$ thick XPS insulation material has been installed on the flooring. There is also an unheated space in the attic. The rock wool insulation on the ceiling was increased from $5 \mathrm{~cm}$ to $9 \mathrm{~cm}$ (Table 8).

5. Deciduous trees were chosen to measure sum-

Table 7. Window areas for existing residential building in Kanlıca

\begin{tabular}{lcccc}
\hline Settlement & Direction & $\begin{array}{c}\text { Existing Building } \\
\text { Window Area }\left(\mathbf{m}^{\mathbf{2}}\right)\end{array}$ & $\begin{array}{c}\text { Renew Building } \\
\text { Window Area }\left(\mathbf{m}^{\mathbf{2}}\right)\end{array}$ & $\begin{array}{c}\text { Change in the } \\
\text { Window Area (\%) }\end{array}$ \\
\hline Kanlica & North & 57.5 & 48.5 & 15.6 reduced \\
& South & 121 & 137 & 13.2 expanded \\
& East & 32.3 & 31.6 & 0.7 reduced \\
& West & 32.3 & 31.6 & 0.7 reduced \\
\hline
\end{tabular}




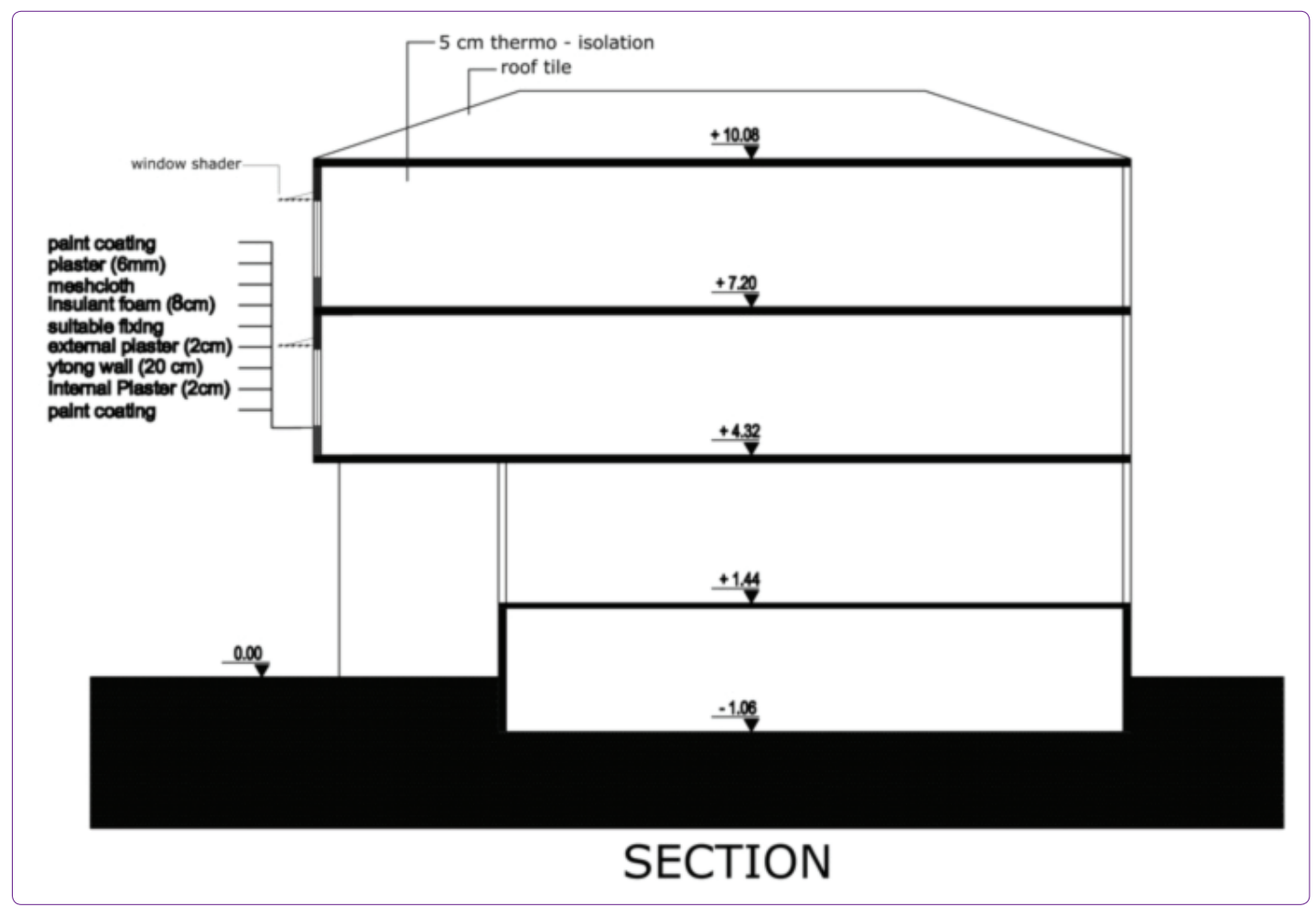

Figure 12. Section indicating the materials used in the renew building.

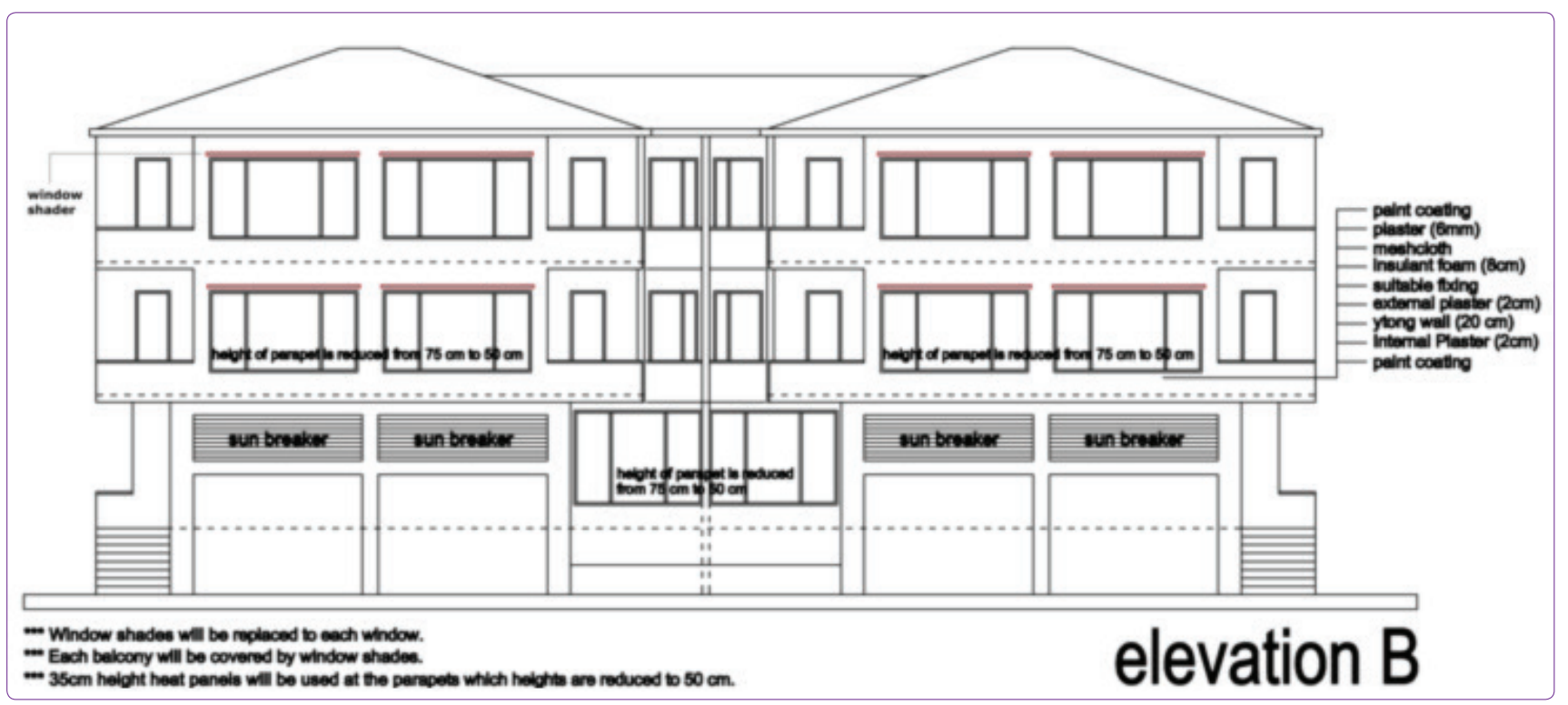

Figure 13. Elevation expressing the materials used in the renew building.

Table 8. Existing and improved UT and Uds values for the building in Kanlıca

\begin{tabular}{llcr}
\hline Settlement & & Existing Building & Renew Building \\
\hline Kanlıca & Uds floor heat transfer coefficient $\left(\mathrm{W} / \mathrm{m}^{2} \mathrm{~K}\right)$ & $3.29 \mathrm{~W} / \mathrm{m}^{2 \circ} \mathrm{K}$ & $1.14 \mathrm{~W} / \mathrm{m}^{2 \circ} \mathrm{K}$ \\
& UT ceiling heat transfer coefficient $\left(\mathrm{W} / \mathrm{m}^{2} \mathrm{~K}\right)$ & $0.65 \mathrm{~W} / \mathrm{m}^{2 \circ} \mathrm{K}$ & $0.39 \mathrm{~W} / \mathrm{m}^{2 \circ} \mathrm{K}$
\end{tabular}


mer shading effect and winter solar heat gain from the trees planted on the south of the buildings. $1 \mathrm{~m}$ long sun breaker awnings were used above the windows on the south to reduce summer cooling loads, increase energy efficiency with effective shading and prevent hot summer sunlight from coming inside. The shading effect of the trees and window awnings on the south facade of the building has provided favourable conditions for summer months. The shading effect of awnings decreases in the winter months, as sunlight angles get lower. The shading effect of the trees and awnings has been calculated hourly according to the angle of sunlight. Figure 14 indicates the effect of these applications for the building in Kanlıca on August $1^{\text {st }}$, at $12 \mathrm{PM}$. Calculations show that the presence of trees would reduce annual cooling energy demand by $4 \mathrm{MW}$.

6. Impermeability measures were applied to reduce drafts in the building. Wall cracks were repaired with sealants. Roof gaps were covered. Drafts from window frames were reduced after renewal of all windows. For the calculations, Ach values for the building were taken as 0.25 for summer and 0.5 for winter. Percolation coefficients for the renew building were taken as 0.15 Ach for summer and 0.25 Ach for winter.

7. Blinds were installed on the windows on the western facades of the building. Wing angles for the blinds were taken as $45^{\circ}$ for the calculations. In this case, sunlight permeability coefficient was taken as 0.21 for the calculations. Total shading coefficient was found by multiplying the sunlight permeability coefficient of the blinds with the shading coefficient of the window.

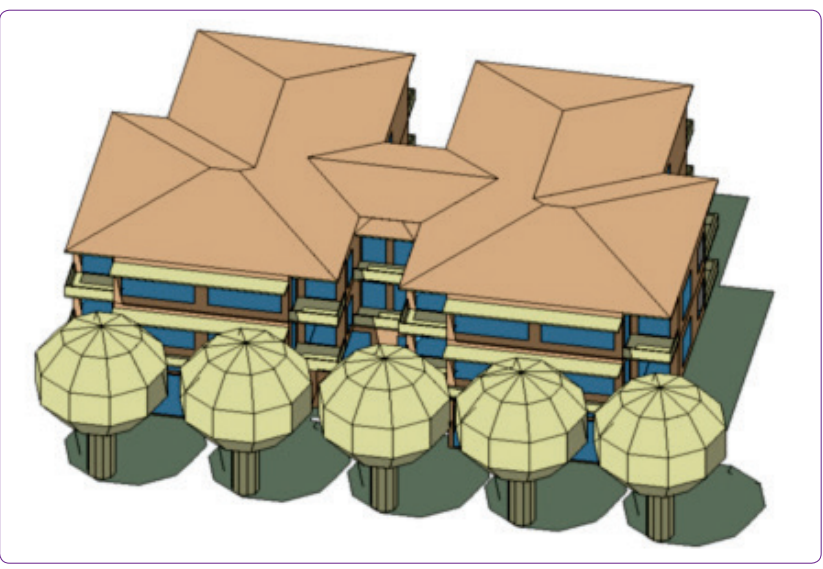

Figure 14. The shading effect of trees and awnings of the building August $1_{\mathrm{st}^{\prime}}$ 12PM.
Blinds were installed on the western facade of this building.

\section{Outcomes}

Energy consumption results before and after the architectural improvements in the selected residential building in Kanlıca have been compared in four categories.

\section{Heating-Cooling Energy Consumption}

An annual $72 \%$ decrease in heating energy consumption was achieved as a result of the improvements. Annual heating energy consumption fell from $85 \mathrm{MWh}$ to $23 \mathrm{MWh}$. Annual cooling energy consumption fell $24 \%$, from $49 \mathrm{MWh}$ to $37 \mathrm{MWh}$. Figure 15a and 15b provide a comparison of these values. Accordingly, the biggest saving in heating energy achieved between November and April, and the biggest saving in cooling energy happened in the period between June and September. The graph shows that the cooling season in Istanbul starts in May and ends in October. Interior loads account for cooling loads in other months.

\section{Amount and Cost of Natural Gas}

Annual amount of natural gas can be calculated

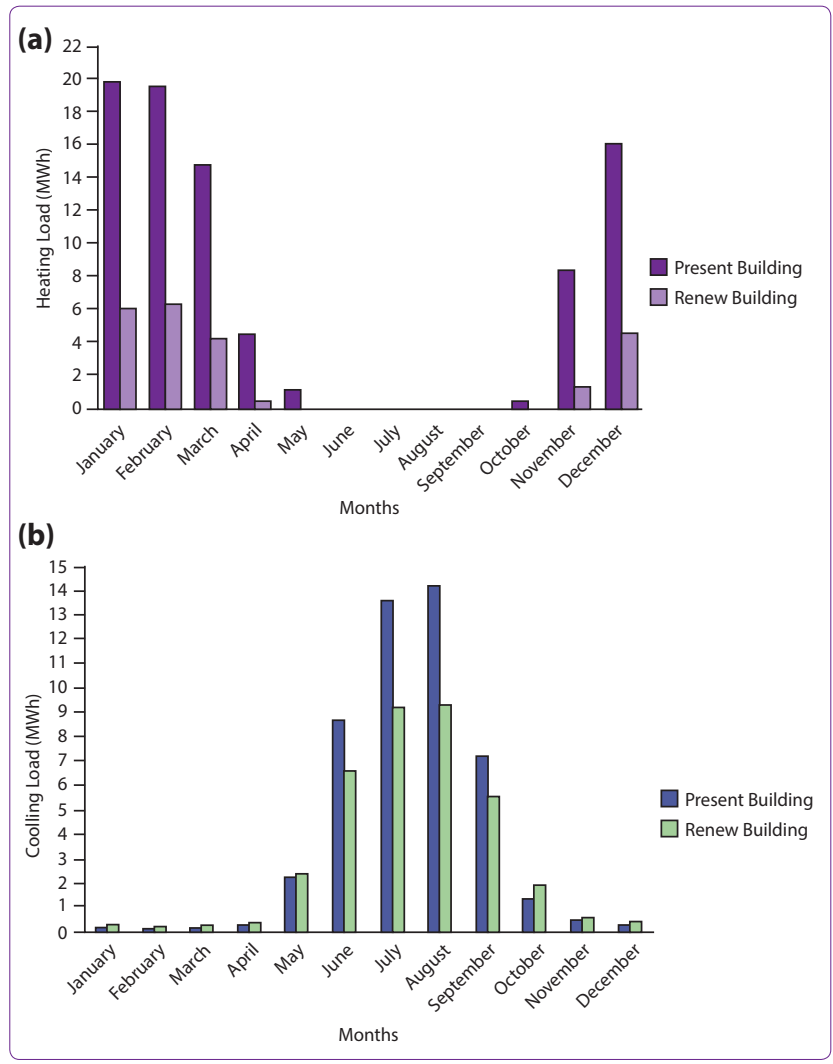

Figure 15a, b. Change in annual heating (above) and cooling (below) energy consumption before and after the improvements. 
based on annual heating energy consumption. The amount of natural gas has been calculated using the formula below:

$$
\text { V=: } \frac{\text { Qheating }}{\text { (Hu. } \mu)}
$$

These calculations reflect conditions before and after the improvements. The unit price of natural gas in Istanbul has been taken as $1.0796 \mathrm{TL} / \mathrm{m}^{3}$ according to Plumbing Magazine (2013) data, and the monetary equivalent (TL-Turkish Lira) of the savings has been determined based on this figure. According to these, the cut in annual natural gas bills is calculated as 7,753 TL for the building (Table 9).

\section{EER and SEER}

EER and SEER air conditioner ratings are used to determine the amount of electricity used for cooling. SEER is an average energy performance value that shows the energy performance of the air conditioner under partial loads and different outdoor tempera- tures, and is calculated using this formula:

SEER=0,03xEER $+0,33 \times$ EER2 $_{1}+0,41 \times$ EER3 $^{2} 0,23 \times \mathrm{EER}_{4}$

Manufacturer catalogues have been studied and a SEER value of 6.5 has been taken for air conditioners (Table 10).

The unit price of electricity in Istanbul has been taken as $0.3738 \mathrm{TL} / \mathrm{kWh}$ according to Plumbing Magazine (2013) data. After comparing the building before and after improvements, annual electricity saving was found to be 732 TL (Table 11).

4-Amount of Annual Greenhouse Gas from HeatingCooling Energy

Total greenhouse gas emissions from heating and cooling fell by $62 \%$ from $28,186.06 \mathrm{~kg} \mathrm{CO}$ equivalent to $10,463.42 \mathrm{~kg} \mathrm{CO}_{2}$ equivalent (Table 12 and 13).

Considering the fact that residential buildings account for $24 \%$ of greenhouse $\mathrm{CO}_{2}$ emissions responsible of pollution and climate change, it becomes evi-

Table 9. Annual natural gas costs of the residential building in Kanlıca before and after improvements

\begin{tabular}{|c|c|c|c|c|c|c|c|}
\hline & $\begin{array}{l}\text { Building } \\
\text { Condition }\end{array}$ & $\begin{array}{l}\text { Annual Heating } \\
\text { Energy (Kwh) }\end{array}$ & $\begin{array}{c}\text { Natural Gas } \\
\text { Lower Calorific } \\
\text { Value }\left(\mathrm{KWH} / \mathrm{M}^{3}\right)\end{array}$ & $\begin{array}{l}\text { Furnace } \\
\text { Efficiency }\end{array}$ & $\begin{array}{c}\text { Annual Natural } \\
\text { Gas Use }\left(\mathrm{m}^{3}\right)\end{array}$ & $\begin{array}{c}\text { Natural Gas } \\
\text { Unit Price } \\
\left(\mathrm{TL} / \mathrm{m}^{3}\right)\end{array}$ & $\begin{array}{c}\text { Cost of } \\
\text { Natural Gas } \\
\text { (TL) }\end{array}$ \\
\hline \multirow[t]{2}{*}{ Kanlıca } & $\begin{array}{l}\text { Current } \\
\text { Condition }\end{array}$ & 85.190 & 9.59 & 0.9 & 9870.24 & 1.0796 & 10.655 .91 \\
\hline & Improved & 23.200 & 9.59 & 0.9 & 2687.99 & 1.0796 & 2.901 .95 \\
\hline
\end{tabular}

Table 10. SEER calculation values for the residential building in Kanlıca

\begin{tabular}{cccc}
\hline Cooling Load Ratio (\%) & Outdoor Temperature $\left({ }^{\circ} \mathbf{C}\right)$ & Energy Efficiency & Operation Time (\%) \\
\hline 100 & 35 & EER1 & 3 \\
75 & 30 & EER2 & 33 \\
50 & 25 & EER3 & 41 \\
25 & 20 & EER4 & 23 \\
\hline
\end{tabular}

Table 11. Annual electricity costs of the residential building in Kanlıca before and after improvement

\begin{tabular}{lcccccc}
\hline Building Condition & $\begin{array}{c}\text { Annual Cooling } \\
\text { Energy (Kwh) }\end{array}$ & $\begin{array}{c}\text { Air Conditioner } \\
\text { SEER Rating }\end{array}$ & $\begin{array}{c}\text { Annual } \\
\text { Electricity } \\
\text { Use (Kwh) }\end{array}$ & $\begin{array}{c}\text { Electricity } \\
\text { Unit Price } \\
\text { (TL/Kwh) }\end{array}$ & $\begin{array}{c}\text { Cost of } \\
\text { Electricity } \\
\text { (TL) }\end{array}$ \\
\hline Kanlica & Current Condition & 47.910 & 6.5 & 7.371 & 0.3735 & 2.752 .98 \\
& Improved & 35.170 & 6.5 & 5.411 & 0.3735 & 2.020 .92 \\
\hline
\end{tabular}


Table 12. Annual amount of heating energy related greenhouse gas for the residential building in Kanlıca before and after improvements*

\begin{tabular}{|c|c|c|c|c|c|c|}
\hline & Building Condition & $\begin{array}{l}\text { Annual Heating } \\
\text { Energy (Kwh) }\end{array}$ & $\begin{array}{l}\text { Annual Heating } \\
\text { Energy }\left(\mathrm{Kwh} / \mathrm{m}^{2}\right)\end{array}$ & $\begin{array}{l}\text { Furnace } \\
\text { Efficiency }\end{array}$ & $\begin{array}{l}\text { Greenhouse Gas } \\
\text { Conversion } \\
\text { coefficient (kg. } \\
\text { equiv. } \mathrm{CO}_{2} / \mathrm{kWh} \text { ) }\end{array}$ & $\begin{array}{l}\text { Annual } \\
\text { Greenhouse Gas } \\
\left.\text { (kg. equiv. } \mathrm{CO}_{2}\right)\end{array}$ \\
\hline \multirow[t]{2}{*}{ Kanlıca } & Current Condition & 47.910 & 6.5 & 7.371 & 0.3735 & 2.752 .98 \\
\hline & Improved & 35.170 & 6.5 & 5.411 & 0.3735 & 2.020 .92 \\
\hline
\end{tabular}

* Coefficients given in "EPB - The Regulation on the Energy Performance of Buildings" guide are used to calculate carbon emissions of the building.

Table 13. Annual amount of cooling energy related greenhouse gas for the residential building in Kanlıca before and after improvements

\begin{tabular}{|c|c|c|c|c|c|c|c|}
\hline & $\begin{array}{l}\text { Building } \\
\text { Condition }\end{array}$ & $\begin{array}{l}\text { Annual } \\
\text { Cooling } \\
\text { Energy } \\
\text { (Kwh) }\end{array}$ & $\begin{array}{l}\text { Annual } \\
\text { Cooling } \\
\text { Energy } \\
\left(\mathrm{Kwh} / \mathrm{m}^{2}\right)\end{array}$ & $\begin{array}{c}\text { Air } \\
\text { Conditioner } \\
\text { SEER } \\
\text { Rating }\end{array}$ & $\begin{array}{c}\text { Annual } \\
\text { Electricity } \\
\text { Use (Kwh) }\end{array}$ & $\begin{array}{l}\text { Greenhouse Gas } \\
\text { Conversion } \\
\text { coefficient } \\
\text { (kg. equiv. } \mathrm{CO}_{2} / \mathrm{kWh} \text { ) }\end{array}$ & $\begin{array}{c}\text { Annual } \\
\text { Greenhouse } \\
\text { Gas } \\
\text { (kg. equiv. } \mathrm{CO}_{2} \text { ) }\end{array}$ \\
\hline \multirow[t]{2}{*}{ Kanlıca } & $\begin{array}{l}\text { Current } \\
\text { Condition }\end{array}$ & 47.910 & 41.95 & 6.5 & 7.371 & 0.819 & 6.036 .66 \\
\hline & Improved & 35.170 & 30.79 & 6.5 & 5.411 & 0.819 & 4.431 .42 \\
\hline
\end{tabular}

*Coefficients given in "EPB - The Regulation on the Energy Performance of Buildings" guide are used to calculate carbon emissions of the building.

dent that work carried out by architects, engineers, urban planners but foremost government officials that develop regulations in this field is very important.

\section{Evaluation}

This study focuses on improvements using architectural and landscaping elements to reduce fuel and electricity consumption in the heating-cooling loads of residential buildings that will acquire energy performance certificates in Turkey by 2015 . The certificate has become mandatory for every building according to the EPB - The Regulation on the Energy Performance of Buildings. The objective of this certificate is to identify energy use performance of existing residential buildings, enter relevant data on the Urban Information System and ultimately increase efficiency. Therefore, based on Istanbul's location and the settlement pattern characteristics of Beykoz District, there will inevitably be a demand for solutions focusing on solar gains, the primary source of renewable energy, and effective use of sunlight in existing residential buildings.

This study proves that, window space, window eaves, window characteristics, exterior wall insulation thickness, draft prevention, shading, landscaping features and control of solar energy in order to it is possible to considerably reduce heating-cooling energy consumption, the amount and cost of natural gas, the amount and cost of electricity, annual greenhouse gas emissions from heating and cooling energy with architectural improvements aimed at energy efficient design on building envelopes. This study offers results of guiding quality and quantity to the municipality, property owner and professionals undertaking these interventions throughout the process of improvements on existing buildings in Beykoz District in order to acquire building energy performance certificates. Moreover, sharing the results of improvements in the sample building in Kanlıca, using architectural and landscaping elements will have an inspiring and encouraging effect on other property owners to use energy efficiently. Implementing architectural improvements developed specifically for a particular location following the investigation of settlements in Turkey will also reduce the foreign dependent energy costs of the country.

On the other hand, this study reminds us again that site selection, orientation, the relations between building-plot-street, building-building and buildinglandscaping elements guided by zoning and planning decisions are effective factors in increasing a building's energy performance and means of utilising sun. Highenergy consumption can be curbed by early precautions in the initial design and planning stage. 


\section{Acknowledgements}

This work was also financially supported by BAP

- Coordination of YTU Scientific Research Projects (MEST, No. 2011-002875), Yıldız Technical University.

\section{References}

Bektaş, B. and Aksoy, U.T. (2005) "Soğuk İklimlerdeki Binalarda Pencere Sistemlerinin Enerji Performansı [Energy Performance of Window Systems in Buildings in Cold Climates]" Science and Engineering Journal of Firat University, 17(3) 499-508.

Cheung, C.K., Fuller, R.J. and Luther, M.B. (2004) "Energyefficient Envelope Design for High-Rise Apartments", Energy and Buildings, (37) 2005, 37-48.

Compagnon, R. (2004) "Solar and Daylight Availability in the Urban Fabric", Energy and Buildings, (36) 321-328.

Çelik, B.Ç., Yılmaz, A.Z., and Corgnati, S.P. (2011) "Konut Binaları Enerji Sertifikasyonunda Isıtma ve Soğutma Enerjisi Ihtiyacının Bina Parametrelerine Duyarlılık Analizi: Bep-Tr Hesaplama Metodolojisi ile Değerlendirme [Susceptibility Analysis of Heating and Cooling Energy Demand in the Energy Certification of Residential Buildings to Building Parameters: Assessment with Bep-Tr Calculation Metholdogy]", Teknik Yayın, 781, 10th National Plumbing Engineering Congress - 13/16 April 2011/izmir, Symposium on Energy Certification in Buildings.

Çomaklı K and Yüksel B. (2003) "Optimum Insulation Thickness of External Walls for Energy Saving", Applied Thermal Engineering, (23) 473-9.

Eskin, N. and Türkmen, H. (2007) "Analysis of Annual Heating And Cooling Energy Requirements for Office Buildings in Different Climates in Turkey", Energy and Buildings, (40) 763-773.

Ferrante, A. and Cascella, M.T. (2011) "Zero Energy Balance and Zero on-site $\mathrm{CO}^{2}$ Emission Housing Development in the Mediterranean Climate", Energy and Buildings, (43) 2002-2010.

Gowri, K., (2004) “Green Building Rating Systems: An Overview", ASHRAE Journal, November) 2004, 56-59.

Güçyeter, B. and Günaydın, H.M. (2012) "Optimization of an Envelope Retrofit Strategy for an Existing Office Building", Energy and Buildings, (5) 647-659.

Hasan A. (1999) "Optimizing insulation Thickness for Buildings Using Lifecycle Cost", Applied Energy, (63) 115-24.

Heravi G. and Qaemi M. (2014) "Energy Performance of Buildings: The Evaluation of Design and Construction Measures Concerning Building Energy Efficiency in Iran", Energy and Buildings, 2014, vol. 75, 456-464.

International Energy Agency-IEA (2014) http://www.iea. org/topics/climatechange/

Integrated Environmental Solutions < Virtual Environment> EIS, (2013).

Jones, D.L. (1998) Architecture and the Environment, Laurence King Publishing.

Kazanasmaz, A., Uygun, I.E., Akkurt, G.G., Turhan, C. and Ekmen, K.E. (2014) "On the Relation Between Architectural Considerations and Heating Energy Performance of Turk- ish Residential Buildings in Izmir", Energy and Buildings (72) 38-50.

Öztürk Kerestecioğlu, F. and Kerestecioğlu, A. (1999) "Bir Konut Uygulaması: Güneş Enerjisi ve Isınma - Sera Etkisi -[Solar Power and Greenhouse Effect: Application on Residence]", Structural Physics - Physical Environment Auditing - Congress Declarations, ed., M. Şerefhanoğlu, Yıldız Technical University School of Architecture Press, Istanbul, 90-92.

Kılıçı, A. (2012) "Binalarda Enerji Verimliliği: UBE Binası Örneği [Energy Efficiency in Buildings: Example of UBE Building]", unpublished Master's thesis, Ege University, Science Institute, Izmir.

Knowsles, R.L. (2003) "The Solar Envelope: Its Meaning for Energy and Buildings", Energy and Buildings (35) 15-25.

Lam. J., Wan, K., Tsang, C. and Yang, L. (2008) "Building Energy Efficiency in Different Climates", Energy Conversion and Management, vol. 9 Issue (8) 2354-2366.

Marks, W. (1997) "Multi-criteria Optimisation of Shape of Energy-Saving Buildings", Building and Environment, vol.32-4, 331-339.

Ozkan D.B. and Onan C. (2011) "Optimization of Insulation Thickness for Different Glazing Areas in Buildings for Various Climatic Regions in Turkey", Applied Energy, (88) 1331-1342.

Roaf, S., Fuentes and M., Thomas, S. (2007) Ecohouse: A Design Guide, Third Edition, Architectural Press.

Soysal, S. (2008) "Konut Binalarında Tasarım Parametreleri ile Enerji Tüketimi illişkisi [The Relation Between Design Parameters and Energy Use in Residential Buildings ]", unpublished Master's thesis, Gazi University, Science Institute, Ankara.

International Energy Agency- EA, (2013) CO2 Highlights 2013, http://www.iea.org/publications/freepublications/publication/name,43840,en.html

United Nations (2014) Gateway to the United Nations System Works on Climate Change, http://www.un.org/climatechange/

Terecia, A., Ozkana, S.T.E. and Eickerb, U. (2013) "Energy Benchmarking for Residential Buildings", Energy and Buildings, (60) 92-99.

Tesisat Dergisi [Plumbing Magazine] (2013) Fuel Prices (www.tesisat.com.tr, 01/04/2013).

Republic of Turkey, Ministry of Energy and Natural Resources (2010) Ministry of Energy and Natural Resources 20102014 Strategic Plan, Ankara.

TurkStat - Turkish Statistical Institute (2012) Annual Population Increase and Urbanisation Ratios in Turkey, Ankara.

The World Bank (2011) Tapping the Potential for Energy Savings in Turkey, January 2011.

General Directorate of Renewable Energy (2014)

http://www.eie.gov.tr/eie-web/turkce/en_tasarrufu/konut_ulas/en_tasarruf_bina_isi.html

Yılmaz, B. (2009) Binalarda Enerji Verimliliği ve Sürdürülebilirlik [Energy Efficiency and Sustainability in Buildings], unpublished Master's thesis, Istanbul Technical University, Science institute, Istanbul.

Yoo, S., Jeong, H., Ahn, B., Han, H., Seo, D., Lee J. and Jang, 
C. (2013) "Thermal Transmittance of Window Systems and Effects on Building Heating Energy Use and Energy Efficiency Ratings in South Korea", Energy and Buildings, 2013, vol. 67, 236-244.

Yu J, Yang C, Tian L. and Liao D. (2009) A Study on Optimum Insulation Thicknesses of External Walls in Hot Summer And Cold Winter Zone of China. Applied Energy, (86) 70-85.

Yumurtacı, Z. and Dönmez, A.H. (2013) "Konutlarda Enerji
Verimliliği [Energy Efficiency in Residences]", engineer and Machine Magazine, Union of Chambers for Turkish Engineers and Architects, Chamber of Mechanical Engineers, book 54, nr.637, 38-43.

Yüksek, İ. and Esin, T. (2011) "Yapılarda Enerji Etkinliği Bağlamında Doğal Havalandırma Yöntemlerinin Önemi [The Significance of Natural Ventilation in context of Energy Efficiency in Structures]", Plumbing Engineering Magazine, (125) 63-77. 